\title{
UNIÃO EUROPÉIA - A ESPERANÇA DE UM MUNDO NOVO*
}

\author{
MARÇAL JUSTEN FILHO**
}

I - A natureza peculiar da construção da UE.; II - Peculiaridades epistemológico-jurídicas em face da UE; III - Breve escorço histórico; $I V-A$ "expansão" objetiva da $U E ; V-A$ "expansão" subjetiva da UE; VI - A estrutura em pilares da UE; VII - A questão da separação de poderes no âmbito da UE; VIII - A competência da UE; VIII.I) Inexistência de regras comuns a todos os pilares; VIII.2) Dupla configuração da UE; VIII.3) Maior consistência de competências no âmbito do primeiro pilar; VIII.4) Ausência de "competência-competência" da UE; VIII.5) Critério enumerativo de discriminação de competências; VIII.6) Classificação de competências; VIII.7) Subsidiariedade e princípios fundamentais sobre competência; IX - Estruturação formal da administração comunitária e a partilha de competências; IX.1) O(s) Conselho(s); IX.2) A Comissão; IX.3) O Parlamento; IX.4) As competências de Conselho, Comissão e Parlamento; IX.5) A Corte de Justiça das Comunidades Européias - CJCE; X - Competências privativas da UE e harmonização de tendências opostas; $X I$ - Nacionalismo e supranacionalismo na estruturação da UE; XII - Consolidação e expansão do Direito Comunitário pela atuação da CJCE; XII.1) Os julgamentos fundamentais; XII.2) A "constitucionalização" do Direito Comunitário; XII.3) Restriçōes passadas, presentes e futuras à atuação da CJCE; XIII - O problema da dimensão meramente "econômica" da Comunidade; XIII.l) Impossibilidade de tutela restrita a Direitos Econômicos; XIII.2) A Intervenção da Corte; XIII.3) A consagração da tutela aos Direitos Fundamentais em Amsterdã; XIV - A produção normativa comunitária propriamente dita e sua eficácia; XIV.1) Fontes formais do Direito Comunitário; XIV.2)

* Estudo produzido durante permanência como Visiting Fellow no Robert Schuman Center (European University Institute) em Florença, com agradecimentos aos Professores Yves Mèny, Gràine de Búrca e Jacques Ziller.

** Professor titular da UFPR.

R. Dir. Adm.,

Rio de Janeiro, 219: 27-89, jan./mar. 2000 
Dualismo e unitarismo no âmbito do Direito Comunitário; XIV.3) A doutrina "Francovich"; $X V$ - Alguns efeitos acessórios da comunitarização; XV.1) A amplitude da comunitarização e os diferentes ramos do Direito; XV.2) A homogenização dos sistemas jurídicos nacionais; XV.3) Superação da dualidade de jurisdições?; XVI - A natureza da UE; XVI.I) A concepção de um Estado regulador; XVI.2) A concepção de um Estado pós-moderno; XVI.3) Estudos "pós-ontológicos"?; XVI.4) A concep̧̧ão tradicional de "Estado" e suas implicações; XVII - A modo de conclusão: cinco minutos de filosofia

A União Européia (UE) é uma organização política com perfil original, a ponto de inviabilizar a aplicação das teorias clássicas no campo da ciência e da filosofia. O presente estudo objetiva expor e comentar alguns aspectos do processo de unificação européia, sem nenhuma pretensão de esgotar (tarefa impossível) os temas nem a bibliografia disponível.

\section{I - A natureza peculiar da construção da UE}

Uma característica essencial da UE consiste na sua "construtitividade", expressão cunhada para indicar a ausência de modelo previamente definido. A UE, tal como hoje a conhecemos, não foi planejada por seus mentores. E o estágio atual é transitório, sem possibilidade de projeções seguras acerca das perspectivas futuras.

Pode afirmar-se que a UE é, antes de tudo, um processo. Corresponde a uma forma especial de organização da conduta conjugada e harmônica dos povos de diferentes Estados europeus, visando a atingir um certo resultado de interesse comum. A concepção processualista tem a virtude de acentuar a ausência de um rompimento histórico abrupto. A UE não foi produzida em virtude de um evento preciso, concentrado no tempo. É impossível estabelecer um marco cronológico determinado, que permitisse organizar o mundo em dois momentos ( $A U$ e $D U-$ Antes da União e Depois da União). Não há como determinar um fato histórico para permitir identificar o "surgimento" de uma situação radicalmente distinta e diversa daquela existente no passado. Não houve uma "revolução comunitária" (a não ser em sentido figurado). A UE é (o resultado de) uma evolução contínua e incessante, cujas diferenças podem ser melhor percebidos pela comparação entre momentos temporais distantes entre si. A continuidade histórica permite preservação dos princípios fundamentais anteriormente incorporados ao acervo cultural comum. Mas também se traduz em desvantagens, pois o ritmo das mudanças é lento, impondo renúncia à realização de propostas radicais.

A UE é um processo também na acepção de ser relevante a dinâmica dos fatos, mais até mais do que o conteúdo deles. O fenômeno UE é produzido por um modo determinado de operação, pela forma como se organizam os fatores econômicos, políticos, jurídicos etc.. A fórmula de organização sócio-política é original e gera 
resultados igualmente peculiares. Nada impede que a UE venha futuramente assemelhar-se a instituições já conhecidas (ainda que tal seja altamente improvável), mas sua configuração sempre será única em virtude do modo de produção: a conjugação dinâmica de esforços de Estados soberanos para produzir associação incindível em que as partes mantenham sua individualidade, superando divergências através de soluções negociadas.

Afirmar ser a UE um processo não importa alguma ideologia "manipulativa", no sentido de que os fatos teriam sido modelados pela vontade de indivíduos ${ }^{1}$ ou organizações privadas ou públicas. Há processo no sentido da sucessão permanente de eventos, entre si relacionados e desenvolvidos com vista ao atingimento de um certo fim, mas com significativa indeterminação no tocante ao resultado a ser atingido. Nem há definição sobre os procedimentos concretos que deverão prevalecer. A relação de poderes entre os Estados-membros não está definida em termos estáveis e pode ser alterada a qualquer momento (tanto assim que já o foi ao longo do tempo).

Em última análise, é possível saber o que a UE foi no passado. É viável avaliar o que é a UE no presente. Mas é extremamerte complexo determinar como UE se configurará no futuro - não apenas na acepção da imprevisibilidade, mas no sentido da ausência de projetos definidos de longo prazo. Essa é uma das peculiaridades da UE, a ausência de projetos (políticos e jurídicos, especialmente) de longo prazo. Aliás, alude-se a "método comunitário" para indicar a peculiaridade da construção "passo a passo", que não exclui a possibilidade de um avante ser seguido de outros para trás (muito pelo contrário). Esse método foi sendo plasmado na medida em que tal se fez necessário, foi influenciado pelas circunstâncias históricas e contingências políticas. A UE se desenvolveu concomitantemente com o método comunitảrio ${ }^{2}$.

No entanto, ao longo dos últimos cinqüenta anos, através desse processo incerto, produziu-se modificação notável no panorama político, jurídico, social e econômico dos Estados integrantes da UE.

\section{II - Peculiaridades epistemológico-jurídicas em face da UE}

A complexidade da UE propicia seu estudo sob diferentes abordagens. No caso, este escrito examina algumas questões sob o ponto de vista jurídico. Não seria viável analisar o que se entende por "ponto de vista jurídico", pois isso pressuporia profundas incursões epistemológicas. Discussão dessa ordem é ainda menos factível em virtude das inovações apresentadas pela própria UE.

1 É verdade que algumas personalidades tiveram papel marcante, especialmente nos estágios iniciais do projeto, tais como Robert Schuman, Jean Monnet e inúmeros outros. Mas essa "influência" tem de ser relativizada em face da dimensão do projeto e da complexidade dos fatores envolvidos.

2 Ou, talvez, possa dizer-se que a UE é o método comunitário. 
Uma causa fundamental da originalidade da UE reside na ausência de preponderância de concepções ou instituições vigentes em um específico Estado-membro. O processo de construção da UE tem natureza dialética, de modo que as contribuições dos diferentes Estados-membros apresentam-se como teses e antíteses. As instituições comunitárias são a síntese dessas contraposições, sempre transcendendo as experiências nacionais. Por isso, o chamado "Direito Comunitário" não pode ser compreendido como a difusão para o âmbito europeu do Direito de um Estado específico. O Direito Comunitário não é o Direito francês aplicado fora das fronteiras da França, nem o Direito alemão ou o Direito inglês transplantados para a dimensão comunitária e assim por diante. Há um Direito novo, produzido a partir das instituições jurídicas dos diferentes Estados, mas com configuraçōes próprias.

Os efeitos são evidentes, especialmente em face da sempre afirmada inconciabilidade dos sistemas jurídicos nacionais europeus. Sempre se considerou que o Direito anglo-saxão era estrutural e funcionalmente diverso do Direito continental. Mesmo a identidade entre os diferentes ordenamentos continentais era relativa: por exemplo, o Direito Administrativo francês apresenta tamanhas peculiaridades em face do alemão que é impossível uma aproximação mais intensa ${ }^{3}$. A estrutura política dos diferentes Estados europeus e as variações culturais não possibilitam um processo de mera soma dos institutos jurídicos de cada Estado. Daí a produção de novos padrões, institutos e modelos cuja origem reside nas diferentes tradições, culturas e organizações políticas, mas que apresentam configuração inovadora.

É importante ter em conta a originalidade do fenômeno UE porque daí deriva a necessidade de estruturação de novos modelos de cunho cognitivo ${ }^{4}$. Se fosse viável impor dissociação entre objeto conoscível e sujeito cognoscente, poder-se-ia afirmar que a peculiaridade ontológica da UE produz correspondente inovação gnosiológica. A UE está originando não apenas modelo novo de Direito, mas também novas concepções de Ciência e Filosofia do Direito. Essas abordagens terão de ser desenvolvidas cautelosamente, à imagem e semelhança do objeto estudado. Tal preocupação permeia o presente estudo, que reconhece a absoluta superação de qualquer pretensão "purista" e a inviabilidade de conceber a "Ciência do Direito" como estudo e conhecimento de um fenômeno isolado, denominado "Direito".

3 Basta considerar que o Direito Administrativo alemão não conhece o conceito de serviço público. Aliás, a expressão francesa é intraduzivel para o alemão. A tentativa de tradução redundaria imediatamente em conteúdo semântico relacionado com servidor público. Sobre o tema, confira-se o sumário de DIMITRIS TRIANTAFYLLOU (Les mutations de la notion de service public en droit comparé em Les mutations de la notion de service public en droit comparé Service Public et Communauté européenne: entre l'interêt général et le marché, Actes du colloque de Strasbourg 17-19 octobre 1996, sous la direction de Robert Kovar et de Denys Simon, Paris, La Documentation française, 1998, vol. I, pp. 33-63).

4 Inclusive no tocante à língua. Por maior que possam ser as reações, a língua mais utilizada no âmbito comunitário é o inglês, inclusive no tocante à produção doutrinária supranacional. Isso conduz à necessidade do domínio do inglês para ter acesso a essa análise. É bem verdade que o processo comunicativo envolve conjugação de diferentes línguas, o que produziu uma síntese denominada "Eurospeaking". 
O surgimento da UE se relaciona à rivalidade franco-germânica, retratada em sucessivas guerras ao longo dos três últimos séculos. 'Ao final da II Guerra Mundial, as perspectivas de renovação de novos conflitos eram alarmantes. Em 09 de maio de 1950, o Ministro do Exterior da França, Robert Schuman, formalizou declaração ${ }^{6}$ propondo união entre França e Alemanha para produção de carvão e aço, como primeiro passo para uma "federação" européia. ${ }^{7}$ Ali se punha o princípio fundamental, que norteou o "método comunitário": "A Europa" não será produzida de uma única vez, ou de acordo com um único projeto. Será construída através de conquistas concretas que primeiro criem uma solidariedade no plano dos fatos". O primeiro passo seria tornar impossível, no plano material, confrontação bélica entre França e Alemanha. Isso se faria através da utilização conjunta dos recursos naturais e da produção de carvão e aço de ambos os países, o que inviabilizaria desenvolvimento de indústrias de armamentos ${ }^{9}$. Mas a proposta foi mais rica, prevendo a criação de uma "Alta Autoridade" com poderes vinculantes sobre os Estados participantes.

A proposta foi aceita pela Alemanha e a ela aderiram a Itália, Bélgica, Holanda e Luxemburgo. Daí resultou o Tratado de Paris de 18 de abril de 1951, criando a Comunidade Européia do Carvão e do Aço (CECA). Foram necessários sete anos (e inúmeros insucessos políticos de tentativas mais ambiciosas) para a assinatura dos Tratados de Roma, que criaram outras duas "comunidades". Foi estabelecida uma "Comunidade Econômica Européia", que definia um mercado comum abrangendo todos os produtos e serviços. Também foi criada a Euratom, a Comunidade Européia da Energia Atômica (CEEA-Euratom).

Sucederam-se eventos orientados à consecução do fim comunitário, produzindo "teia" de fatos jurídicos, políticos e econômicos e ampliando a solidariedade fática e a vinculação dos diferentes países, ainda que de modo muitas vezes imperceptível. É impossível arrolar todos os fatos relevantes, muitos dos quais ocorridos no seio de órgãos instituídos pelos Tratados (por exemplo, a extraordinária atuação da Corte de Justiça no período de 1960 a 1990). Outros envolveram negociações multilaterais

5 Acerca das origens da EU, confira-se DENYS SIMON, Le système juridique communautaire, Paris, PUF, 1998, $2^{\mathbf{a}}$ ed., pp. 15-41, e IAN WARD, A Critical Introduction to European Law, London-Dublin-Edinburgh, Butterworths, 1996, pp. 1-16.

6 Redigida por Jean Monnet.

7 O texto integral da declaraçāo pode ser consultado através da Internet, no site específico da UE, em que se contêm todos os documentos fundamentais (www.europa.eu.int).

8 A utilização do "Europa" para identificar a UE ou a nova situaçāo gerada envolve inúmeras perquiriçōes filosóficas e retrata posicionamentos ideológicos marcantes. Acerca dessa dimensão lingüística do fenômeno, WEILAR assinala que, " [N]o discurso público, 'Europa' crescentemente significa a Comunidade Européia em termos muito semelhantes ao em que 'América' significa os Estados Unidos" (The Constitution of Europe, Cambridge, Cambridge University Press, 1999, p. 112).

9 A menos, naquele estágio tecnológico e em face dos processos então vigentes de produção de armamentos. 
entre alguns países (por exemplo, o chamado "acervo de Schengen". compreendendo os acordos de 14 de junho de 1985 e 19 de junho de 1990, na cidade de Schengen, firmados entre Bélgica, República Federal da Alemanha, França, Luxemburgo e Holanda, de que se seguiram inúmeras decisões e atos derivados). Costumam-se indicar, no entanto, alguns momentos de maior consistência formal, em que se cristalizaram as inovações conquistadas e se introduziram novas perspectivas para o desenvolvimento do projeto.

Pode referir-se ao Ato Único Europeu (14 e 28 de fevereiro de1986), que introduziu modificações sensíveis no Tratado da Comunidade Econômica e viabilizou a dinamização do processo de integração. Depois, foram firmados os Tratados de Maastricht de 7 de fevereiro de 1992, superando a concepção de comunidade meramente econômica e consolidando a idéia da União. Em 2 de outubro de 1997, firmaram-se os Tratados de Amsterdã, que entraram em vigor em 01 de maio de 1999.

É importante assinalar a coexistência de uma pluralidade de Tratados. Continuam em vigor os de 1950 da CECA e de 1957 da CEEA, ainda que alterados em inúmeros dispositivos. O Tratado da Comunidade Econômica de 1957 foi profundamente modificado pelo Ato Único de 1986 e, depois, em Maastricht (1992) e Amsterdã (1998). Em Maastricht, foi firmado outro Tratado, instituindo a UE, que também objeto de revisão em Amsterdã.

Em suma, existem diversos Tratados a considerar, dos quais dois apresentam maior relevância. São os que disciplinam a Comunidade Européia (antigo Tratado da Comunidade Econômica Européia, de 1957) e a UE. Rigorosamente, é incorreto aludir simplesmente a "Tratado de Amsterdã", eis que foram firmados Tratados distintos. Para evitar dúvidas, referir-se-á a TUE (Tratado da UE) e a TCE (Tratado da Comunidade Européia) como dois diplomas diversos.

Nessa linha, é importante destacar que UE não é expressão sinônima de "Comunidade Européia". Em termos simplísticos, a UE é o conjunto das instituições identificadas como "Comunidades" e daquelas pertinentes à Política Externa e de Segurança Comuns e à Cooperação Policial e Judiciária em Matéria Penal - temas cuja compreensão melhor se fará em face da concepção dos "pilares", abaixo exposta.

\section{IV - A "expansão" objetiva da UE}

Uma das maiores dificuldades na estudo do fenômeno UE reside na sua dinamicidade, que se retrata não apenas nessa sucessão de diplomas constitutivos.

Sob um primeiro ângulo, nenhum dos tratados institutivos da UE foi concebido como permanente ou destinado a vigência ilimitada. Foram elaborados como diplomas destinados a existência mais ou menos curta. Há perspectiva de sua substituição, em futuro não muito distante, por diplomas que incrementem a evolução do projeto de unificação européia. Os tratados cristalizam um momento do percurso em direção ao objetivo - o qual, como apontado, vai sendo construído juntamente ao longo do 
próprio percurso. Por isso, é problemático aludir a uma "mens legislatoris" para os Tratados, nem mesmo para afirmar ser ela irrelevante.

Mas mesmo "mens legis" acaba sendo noção pouco adequada. Justamente por essa característica de auto-referibilidade, o conteúdo dos Tratados não é delimitado ou definido. Eles têm de ser interpretados como instrumentais, na acepção de que suas regras são meio de atingir certo objetivo, que é relativamente indeterminado, consistente na Europa unificada. A cada etapa do percurso histórico, vai aumentando a consistência de projeto. Isso se reflete no processo de aplicação-interpretação dos Tratados, que adquire natureza claramente constitutiva. Vigora concepção teleológica, em que o fim a atingir determina o meio a utilizar. Transplantando para termos jurídicos: o fim buscado pelo ordenamento condiciona a interpretação para as regras e princípios considerados. Como não existe fim definido previamente, antes ele é construído em cada oportunidade, o resultado é peculiar e incomparável a qualquer outra situação jurídica existente ao nacionalmente. É necessário avaliar o percurso do passado e conjugá-lo com as perspectivas futuras para determinar o sentido das regras comunitárias ${ }^{10}$.

A dimensão da UE e do Direito Comunitário vê-se se ampliando, lenta e continuamente. Aquilo que era uma comunidade econômica foi transformado em comunhão com dimensões muito mais amplas. O Direito local de cada Estado soberano foi (e continua a ser) cada vez mais afetado. A harmonização e a uniformização das legislações atingiu a todos os setores da atividade econômica e está indo mais além. Esse fenômeno é denominado por alguns de "constitucionalização" e será adiante melhor examinado. Compreender a UE significa adaptar-se a essa contínua ampliação de limites do objeto estudado.

\section{$\mathrm{V}-\mathrm{A}$ "expansão" subjetiva da $U E$}

Seis Estados firmaram os Tratados de Roma de 25 de março de 1957 (Alemanha, Bélgica, França, Holanda, Itália e Luxemburgo). Com o passar do tempo, outros países europeus aderiram à unificação. Em 1973, o Reino Unido, a Dinamarca e a Irlanda ingressaram na Comunidade. Em 1979, houve o acesso da Grécia. Espanha e Portugal acederam à Comunidade em 1985. Em 1995, Áustria, Finlândia e Suécia passaram a participar da UE. Lembre-se que Noruega, Islândia e Liechtenstein participam do Espaço Econômico Europeu, o que significa uma acentuada integração econômica, sem atingir à dimensão política derivada das regras comunitárias.

Outros países pretendem integrar a estrutura comunitária" ${ }^{11}$. No entanto, qualquer ampliação subjetiva deverá ser precedida de modificações estruturais da UE, cujo

10 Essa construção nāo deixa de lembrar a proposta de DWORKIN acerca da atividade de aplicação do Direito como uma sucessão de autores encarregados de dar continuidade a uma estória iniciada anteriormente, o que destaca o dever de coerência com o passado e a abertura para o futuro.

11 Malta, Chipre, Turquia, Hungria e outros países da Europa Central já externaram essa intenção. 
sistema decisional não comporta simples ampliação quantitativa, sob pena de sua inviabilização ${ }^{12}$.

Deve ressaltar-se, por outro lado, que a abrangência dos Tratados não é uniforme relativamente a todos os Estados signatários. Existem inúmeros protocolos, ressalvando a aplicação de regras e princípios no tocante aos diferentes Estados. Apenas para exemplificar, importantes regras acerca de supressão gradual de controles nas fronteiras comuns, produzido no âmbito do denominado "Acervo de Schengen", não se aplicam à Grã-Bretanha e Irlanda.

\section{VI - A estrutura em pilares da $U E$}

A partir do Ato Único Europeu, generalizou-se uma figuração simbólica para explicar a estruturação da UE. Essa construção verbal foi institucionalizada com os Tratados de Maastricht, de tal modo que se tornou impossível discutir a UE sem dominar esses conceitos figurativos, que apresentam grande utilidade didática e comunicacional.

A partir da idéia da UE como um "edifício europeu", desenvolveu-se uma metáfora arquitetônica, por assim dizer, cuja maior riqueza consiste na explicitação dos "pilares" (ou "colunas"). Afirmou-se que as fundações da UE consistem nas tradições comuns aos diferentes povos europeus. O telhado corresponde às instituições democráticas. Haveria três pilares (e um quarto virtual) a dar consistência à UE.

O primeiro pilar é constituído pelas três "comunidades" (Européia ${ }^{13}$, CECA e CEEA), que asseguram não apenas o mercado único, mas coesão social e política entre os povos dos diferentes países integrantes da UE. O tema está disciplinado nos três Tratados específicos, acima referidos.

O segundo pilar é a Política Externa e de Segurança Comum (conhecido pelas siglas PESC, em francês, ou CFSP, em inglês) e está regulado no Título V do TUE (arts. 11 a 28). Aí se descortina a natureza complexa da UE, eis que se define a existência de um corpo orientado a assegurar a unidade e harmonia no âmbito do relacionamento com os demais sujeitos integrantes do concerto das Nações. Impõem-se deveres de ação e de omissão aos Estados membros, para assegurar a "salvaguarda dos valores comuns" (art. 11, § 1ª, "a"), prevendo-se atuação uniforme no âmbito de organizações e conferências internacionais.

12 Há um protocolo específico acerca da necessidade de revisão das estruturas da UE, em caso de ingresso de novos Estados-membros. Sobre o tema, consulte-se CHRISTOPHER PRESTON, Obstacles to EU Enlargement: The Classical Community Method and the Prospects for a Wider Europe, Journal of Common Market Studies, vol. 33, n² 3, September 1995, pp. 451-463.

13 Não é casual a supressão da expressão "Econômica" para identificar a "Comunidade Européia". As regras do Tratado de Roma foram acrescidas de dispositivos sobre inúmeros campos (sociais, educacionais, ecológicos etc.). No entanto e mesmo alterada a fórmula verbal tradicional, a Comunidade é sempre relacionada a alguma dimensão econômica. tal como adiante se evidenciará. 
O terceiro pilar é a Cooperação Policial e Judiciária em Matéria Penal (conhecido pelas siglas CAIJ, em francês, e CJHA, em inglês. em homenagem à redação do Tratado de Maastricht). As regras constam do Título VI do TUE (arts. 29 a 42), que consolidam idéia de combate conjunto à criminalidade. inclusive com cooperação estreita entre forças policiais, a desdobrar-se no âmbito de um Serviço Europeu de Polícia (Europol). ${ }^{14}$

Cogita-se de um quarto pilar, dito virtual em face da ausência de implementação concreta efetiva. Trata-se da Cooperação Reforçada, consistente na possibilidade de as instituições e previsões dos Tratados serem utilizadas para outros fins além daqueles previstos. Essa sistemática permitiria que os mecanismos comunitários não fossem bloqueados definitivamente em caso de oposição incontornável de um ou mais Estados-membros: os demais poderiam recorrer à fórmula da cooperação reforçada para manter em curso iniciativas de interesse comum. Até o presente, no entanto, não existe nenhuma manifestação efetiva e real de implementação de atividade correspondente.

A simbologia dos pilares foi produzida em virtude da expansão do projeto de unificação européia. O Tratado de Roma abrangia basicamente o domínio econômico: as três comunidades se restringiam a congregar diferentes Estados no âmbito de atividades economicamente relevantes. As inovações trazidas a partir do Ato Único ampliaram a abrangência do que se poderia denominar "projeto Europa". Outros aspectos foram incorporados no âmbito desse projeto, mas subordinados a regime político-jurídico diverso daquele previsto nos Tratados originais. A expressão "pilares" é útil porque descreve duas características fundamentais dessa evolução. Por um lado, as novas manifestações de "europeização" são extremamente relevantes. Por outro, sâo inconfundíveis com aquelas delineadas na origem da vida comunitária. Com rigor. a adoção dos outros dois pilares representou não apenas mudança quantitativa, mas modificação qualitativa. Seguindo essa linha, é incorreto afirmar que, antes da instituição do segundo e terceiro pilares. o edifício se fundava em ponto de apoio único. Deve afirmar-se que, enquanto havia apenas as Comunidades, não havia edifício. Compreender essa transformação significa compreender a diferença entre "UE" e "Comunidade Européia". A UE é a conjugação de propostas preponderante (mas não exclusivamente) econômicas com compromissos de ordem político-institucional, em especial quanto ao relacionamento com terceiros Estados. Não é possível considerar UE e Comunidade Européia como equivalentes, porque esta está compreendida por aquela. Logo, Comunidade Européia tem dimensão mais restrita do UE ${ }^{15}$.

i4 A Europol é uma "agência européia", o que propicia cogitaçōes as mais interessantes acerca da sua natureza jurídica e da função jurídica que desempenha, especialmente tendo em vista a dificuldade de controle de sua constituição e de suas atividades. Porém, o tema escapa aos limites deste estudo.

15 Apesar disso, utilizar-se-á o vocábulo "comunitário" como adjetivo correspondente ao substantivo "União Européia" tanto quanto para aquele "Comunidade Européia". No rigor técnico-jurídico. tal opção é incorreta e somente se justifica pela absoluta ausência de difusão do adjetivo 
A relevância prática da simbologia dos pilares relaciona-se à existência de diferentes regimes jurídicos para as matérias submetidas a cada um deles. Cada qual apresenta disciplina jurídica, princípios e competências próprios. Advirta-se ser impossível estabelecer regras uniformes aplicáveis a todas as matérias contidas no âmbito de cada pilar. Existe uma espécie de regra geral, com exceções diversas. Por exemplo, a regra é de que todos os atos no âmbito do primeiro pilar estão sujeitos ao controle da Corte de Justiça das Comunidades Européias (CJCE). Já as ocorrências sujeitas ao âmbito dos outros dois pilares não podem ser objeto de controle através da Corte, como regra. Em última análise, o segundo e o terceiro pilares envolvem matéria pertinente a questões ditas usualmente "políticas", quanto às quais a unificação européia é muito mais problemática.

O simbolismo arquitetônico não deve ser levado às últimas conseqüências. Em primeiro lugar, não deve supor-se que a dimensão dos três pilares seja equivalente, especialmente em termos de extensão normativa. Há quantidade muito mais extensa de temas sujeitos ao âmbito do primeiro pilar do que quanto aos demais. Em segundo lugar, nada impede o "deslocamento" de matérias de um pilar para outro. Isso se passou especificamente no caso do Tratado de Amsterdã, em que setor significativo de temas antes enquadrados no âmbito do terceiro foi deslocado para o primeiro pilar $^{16}$. Para ser mais preciso, o regime jurídico aplicável a um certo conjunto de assuntos deixou de ser aquele previsto para o terceiro pilar e passou a ser o do primeiro. Ou seja, não é possível estabelecer uma espécie de distinção de "natureza essencial" entre as matérias contidas em cada pilar, tal como se fossem inconfundíveis entre si. A diferença entre elas deriva de escolhas (políticas) realizadas pelos Estados-membros. Em terceiro lugar, a distinção entre pilares não envolve, de modo imediato, a aplicação de qualquer teoria tradicional de "separação de poderes". A tripartição em pilares não se vincula à teoria da tripartição de poderes, ainda que se refira, em última análise, uma problemática de limitação e equilíbrio (tal como adiante se verá).

Não falta quem rejeite a adequação do simbolismo dos três pilares. JOSEPH H. H. WEILER observou que metáfora mais adequada seria a da Trindade (um e três ao mesmo tempo $)^{17}$. Com argúcia invejável, o autor demonstra que a distinção dos três pilares não corresponde à visão usualmente adotada nem apresenta a consistência que uma abordagem superficial produziria. Por fim, deve reconhecer-se que a primazia do primeiro pilar não significa a irrelevância dos demais, o que é evidenciado até por dados estatísticos. Até novembro de 1997, tinham sido adotados 250 textos normativos no âmbito do terceiro pilar (CJHA). Mas existiam mais de 3.000 docu-

(teoricamente mais adequado) "unionístico". Seria despropositado, por outro lado, valer-se de "federal".

16 Tratou-se dos temas atinentes a vistos, asilo, imigração e outras políticas relacionadas ao livre trânsito de pessoas.

17 Neither Unity nor Three Pillars - The Trinity Structure of the Treaty on European Union, em The Maastricht Treaty on European Union, Legal Complexity and Political Diversity, 1993, European Interuniversity, pp. 49-61. 
mentos produzidos acerca desses temas no âmbito apenas no Conselho, sem considerar outras decisões de cunho plurilateral. A natureza das questões no âmbito do segundo pilar exclui produção quantitativa tão intensa. Mas os dados nessa área também são relevantes. No período de novembro de 1993 até maio de 1998, as decisões na área de CFSP formalizaram-se em 58 posições comuns e 69 ações conjuntas $^{18}$.

\section{VII - A questão da separação de poderes no âmbito da $U E$}

Como se passa em toda organização, a UE envolve problema de divisão (atribuição) de poder, com a agravante de sua natureza supranacional. No âmbito do Direito interno, a temática do poder desenvolve-se basicamente no plano intersubjetivo. A disputa pelo poder envolve conflitos entre pessoas ou grupos de pessoas, individualizáveis em face dos interesses que titularizam. Essa problemática não se põe no tocante à UE, eis que não existe poder exercido pelos órgãos comunitários no relacionamento direto de sujeitos privados ${ }^{19}$. A disputa pelo poder de dispor sobre os interesses privados se resolve (pelo menos, teoricamente) no âmbito de cada Estado-membro. A questão fundamental do poder, no âmbito da UE, desenvolve-se no âmbito supra-individual, na relação entre Estados-membros (entre si e em face da UE). A organização da UE não se conecta com a disciplina do poder exercitado em face dos cidadãos, mas se preocupa com a organização dos Estados-membros, desdobrando-se em dois planos.

Em primeiro lugar, há a questão da divisão de poderes dos diferentes Estadosmembros entre si. Os instrumentos político-jurídicos da UE destinam-se a controlar a concentração de poder e evitar que um deles prepondere sobre os demais. Esse é um tema fundamental, sempre presente em qualquer relacionamento entre Estados soberanos.

Mas há outro ângulo do tema, que apresenta contornos mais agudos e teoricamente mais complexos. Trata-se da configuração de um poder supranacional. A UE não consiste em mera manifestação dos Estados-membros. Existem órgãos comunitários, titulares de competências próprias, oponíveis às detidas pelos Estados. A associação interestatal gerou algo mais do que a mera soma de partes. A organização, em si própria, adquiriu certo cunho de "sujeito", competindo por parcelas de poder

18 CURTIN e DEKKER, The European Union as a "Layered" Intermational Organization: Institutional Unity in Disguise, texto a ser incluido em The Evolution of EU Law (org. por CRAIG e DE BURCA), texto impresso, pp. 18, 36 e 37.

19 A afirmativa é questionável, eis que um sujeito privado pode provocar a atuação dos órgãos comunitários. Mas a jurisprudência da CJCE repele a possibilidade de impugnação direta dos atos reputados inadequados. Nesse sentido, pode lembrar-se julgado em que se estabeleceu que "Não $e ́$ autorizado a particulares promover ação contra a recusa pela Comisão de iniciar procedimentos fundados no art. 169 contra um Estado-membro" (Caso C-107/95 P, [1997] ECR I-948). 
perante os Estados-membros. Sob esse enfoque. a UE não é simplesmente um "conjunto" de Estados soberanos, mas se configura como sujeito autônomo ${ }^{21}$. É verdade que essa temática é sempre enfrentada no caso de Estados federados. Questões dessa ordem sempre se põem quando diferentes órbitas de poder coexistem no âmbito de um mesmo território ${ }^{21}$. A definição da extensão dos poderes centrais e locais acaba por determinar a natureza jurídica do Estado, propiciando a classificação de diferenciação formas de Estados. A sistemática de separação de poderes na UE envolve o equilíbrio de interesses nacionais entre si e em face de um "ente central", em termos comparáveis aos conhecidos pela Teoria Geral do Estado. Mas a riqueza do modelo da UE reside na originalidade do sistema de partilha de competências, tal como evidenciado pela doutrina e como se tentará reproduzir abaixo.

\section{VIII - A competência da UE}

A distribuição de competências no âmbito da UE não seguiu o modelo norteamericano. As principais diferenças estão expostas adiante.

\section{VIII.1) Inexistência de regras comuns a todos os pilares}

A primeira característica é a heterogeneidade de critérios de partilha de competências. Cada pilar tem regras próprias e diferenciadas. Mesmo os temas abrangidos em um único pilar recebem tratamentos diversos. Portanto, deve tomar-se cautela com formulações que se pretendam abrangentes, porque serão incorretas.

\section{VIII.2) Dupla configuração da UE}

Outra peculiaridade somente pode ser compreendida através da análise da estrutura organizacional da UE, examinada a seguir. Devem distinguir-se duas formas de atuação da UE. Em alguns casos, a UE surge como um conjunto de Estados soberanos que atuam em conjunto, segundo um critério de unanimidade. Já em outras hipóteses, reconhece-se relativa autonomia da UE em face dos Estados-membros. Essa situação está no núcleo das disputas acerca da própria natureza jurídica da UE.

Seria simplismo classificar as competências como pertencentes ou aos Estadosmembros ou à UE. É necessário distinguir não duas mas três órbitas de titularidade de competência. Há as competências próprias dos Estados-membros, isoladamente

20 Outra é a questão de determinar se a UE se configura como um Estado. O tema será enfrentado mais adiante. Por ora, basta considerar que existem competências comunitárias oponiveis àquelas titularizadas pelos Estados-membros.

21 Sob um certo ângulo, essa é a discussão quando se propicia a diferenciação entre interesses federais e nacionais. 
considerados ("competências nacionais próprias"). Há as competências da UE, mas enquanto considerada como via de exercício de posições nacionais uniformes ("competências nacionais conjuntas"). E há as competências da UE como entidade autônoma ("competências supranacionais"). Logo, a expressão "competências comunitárias" deve ser examinada com cautela, porque abrange situações muito distintas entre si.

Em síntese, há certas decisões que cada Estado pode adotar isoladamente. Há outras decisões que são tomadas pelos Estados em conjunto. Por fim, existem aquelas que são tomadas ou sem manifestação direta dos Estados ou pela vontade da maioria deles.

\section{VIII.3) Maior consistência de competências no âmbito do primeiro pilar}

A UE detém competência supranacional mais ampla no âmbito das matérias compreendidas no primeiro pilar (comunidades). Nos temas pertinentes aos demais pilares, a competência comunitária é de tipo conjunta: os Estados-membros atuam em conjunto, deliberando por unanimidade (como de regra) e sem poder autônomo para os órgãos comunitários. Nesse setor, é problemático aludir à UE como sujeito diferenciado do conjunto dos Estados-membros. É diversa a situação no âmbito do primeiro pilar, em que há inúmeras hipóteses de deliberação por maioria e de atuação em nome próprio dos órgãos comunitários.

\section{VIII.4) Ausência de "competência-competência" da UE}

Pode afirmar-se que a UE não é titular de competências originárias próprias, na acepção de soberania. Não detém poder de definir a própria competência (competência-competência) ${ }^{22}$, mas recebe poderes dos Estados-membros. Ou seja, a UE se sujeita ao princípio da especialidade, no sentido de que seus poderes são limitados e específicos ${ }^{23}$. Bem por isso, toda atuação comunitária tem de indicar sua "base legal", expressão que indica o dispositivo normativo que lhe dá fundamento.

Vige concepção de cunho formalista, conducente à restrição dos poderes da UE às hipóteses contidas em textos normativos fundamentais. Mas os Tratados não são interpretados pelo chamado "método gramatical", senão que segundo concepção teleológica. É insuficiente afirmar que os Estados-membros atribuíram certos poderes

22 A afirmativa é mais procedente do ponto de vista teórico do que prático. A atuaçāo da Corte de Justiça parece ter desmentido esse postulado genericamente admitido.

23 Mas JOSEPH WEILAR afirma que, "embora isso nunca tenha sido explicitamente afirmado, a Corte tem a 'Kompetenz-Kompetenz' na ordem legal Comunitária, i. e., é o corpo que determina quais normas entram dentro da esfera de aplicação da lei Comunitária" (The Constitution of Europe, Cambridge, Cambridge University Press, 1999. p. 21). É possível que a afirmativa se aplique ao âmbito interno da Comunidade, mas afirmar a titularidade desse poder internamente produz sua configuraçāo no plano externo, igualmente. 
à UE, porque foram a ela atribuídos poderes para realizar certos fins. A conseqüência imediata reside na distinção entre poderes explícitos e implícitos. Os poderes da UE são limitados ${ }^{24}$, mas isso não importa negar poderes implícitos ${ }^{25}$.

A fórmula se aplica claramente às competências do primeiro pilar. Inúmeros dispositivos do TCE autorizam adoção de medidas outras além das explicitamente previstas. Como resultado, a delimitação dos limites da competência da UE é muito problemática.

Para ampliar as dificuldades, o art. 308 do TCE $^{26}$ faculta à UE exercer outros poderes além daqueles (explícita ou implicitamente) recebidos dos Estados-membros, desde que respeitado procedimento rigoroso. A regra produziu dúvidas e problemas práticos. A Corte esclareceu que o dispositivo não se destina a "modificar" o conteúdo do Tratado, estatuindo que o "Artigo $235^{27}$ destina-se a preencher lacunas quando nenhuma previsão específica do Tratado confere às instituições da Comunidade poderes expressos ou implícitos para agir, se tais poderes configurarem-se apesar disso como sendo necessários a propiciar à Comunidade o desempenho de suas funções em face da satisfação de um dos objetivos estabelecidos pelo Tratado... Por outro lado, o art. 235 não pode ser utilizado como fundamento para a adoção de previsóes cujo efeito poderia, substancialmente, corresponder a emendar o Tratado sem seguir o procedimento que é previsto para tal propósito". ${ }^{28}$

Extrai-se daí a distinção entre "poder implícito específico" e "poder implícito genérico". Aquele deriva de alguma disposição determinada do TCE, que fixe competência inquestionável para a Comunidade mas omita atribuição explica dos poderes adequados à consecução do fim. Essa hipótese não se confunde com a outra, em que não existe explicitação da competência da Comunidade, mas é inquestionável que um certo fim se enquadra em seu âmbito de atuação. Não havendo possibilidade de submeter a situação ao âmbito de dispositivo determinado do TCE, aplica-se o art. 308. Porém, não se poderá utilizar o dispositivo para atribuir poderes à Comunidade quando for impossível submeter a atividade a princípio fundamental ou a fim genérico previsto para ela. Em tal hipótese, a única alternativa será a alteração do próprio Tratado.

24 Ao menos, em tese.

25 A Corte de Justiça já decidiu que "Quando um artigo do Tratado da Comunidade Econômica Européia confere uma função específica à Comissāo, deve ser aceito, se não se quiser transformar essa disposição em totalmente inefetiva, que ele confere à Comissão necessariamente e por si só os poderes que forem indispensáveis ao cumprimento daquela funçāo (Casos 281, 283 a 285 e 287/85, [1987] ECR 3.205).

26 A redação do dispositivo é a seguinte: "Se uma ação da Comunidade afigurar-se necessária para realizar, no âmbito do funcionamento do mercado comum, um dos objetivos da Comunidade, sem que o presente tratado tenha previsto os poderes de ação necessários a tanto, o Conselho, deliberando à unanimidade em virtude de proposição da Comissão e depois de consulta ao Parlamento europeu, tomará as determinações apropriadas".

27 Correspondente ao atual art. 308, na redação adotada em Amsterdã.

Opinião 2/94 [1996] ECR I-1788. 
É claro que a distinção é mais simples de fazer-se no plano teórico do que na aplicação prática. Antes de tudo, é questionável afirmar que a evolução da UE fez-se dentro dos limites dos poderes conferidos (ainda que genericamente) pelos Tratados. De toda a forma, dois casos concretos ilustram a aplicação (e os limites) do art. 308.

No Caso $242 / 87^{29}$, a Corte examinou impugnação da Comissão contra ato do Conselho fundado no art. 235 (hoje art. 308, como visto). A questão envolvia o chamado "Programa Erasmus", destinado a promover intercâmbio entre estudantes e outras atividades de cunho educacional. A Comissão sustentou existirem poderes implícitos, derivados do art. 128 (hoje art. 151 ) $^{30}$. A Corte rejeitou a impugnação por entender que o Programa Erasmus não envolvia simplesmente questões educacionais ou culturais. Nenhum dispositivo do Tratado autorizava edição daquelas regras por órgãos comunitários. No entanto, as políticas previstas no Programa estavam contidas no âmbito da Comunidade. Ou seja, não havia poderes mas o ato não extrapolava os limites do Tratado.

Já no caso da Opinião $n^{2} 2 / 94$, questionou-se a possibilidade de a UE firmar a Convenção Européia de Direito Humanos. Ainda reconhecendo que o respeito aos Direitos Humanos entranhava o espírito dos atos comunitários, a Corte decidiu ser incompatível com as propostas e os fins dos Tratados o ingresso da UE em sistema institucional internacional. Era necessária modificação do Tratado para que tal se desse. Aliás, esse foi um dos motivos para o reconhecimento formal dos Direitos Humanos através dos Tratados de Amsterdã ${ }^{31}$.

Como se vê, a concepção de competências delimitadas têm de ser enfocada com cautela. Os poderes da UE estão contidos nos limites globais dos fins buscados através dos Tratados. Como esses fins são relativamente imprecisos, torna-se problemático afirmar que as competências comunitárias são aquelas atribuídas previamente pelos Estados-membros.

\section{VIII.5) Critério enumerativo de discriminação de competências}

Outra característica dos Tratados é a ausência de critérios materiais abrangentes para discriminação de competências. Por exemplo, não se estabelece incumbir à UE dispor sobre "direito comercial". Em cada tema, estabelecem-se fórmulas enumerativas de competências, o que inviabiliza uma sistematização. Não se adotam previsões exaustivas, o que propicia inclusive disputas sobre a natureza exemplificativa da regra.

29 [1989] ECR 1425-1.460.

30 Os motivos práticos da impugnação eram compreensíveis. O procedimento fixado para atos baseados no art. 235 era distinto daquele dos atos respaldados pelo art. 128 , inclusive no tocante à amplitude de intervenção da Comissão. Portanto, a questão envolvia uma disputa interna de poder entre Conselho e Comissão, algo extremamente comum na vida comunitária.

31 Sobre o tema dos Direitos Humanos, confira-se abaixo. 
A dificuldade é ampliada em virtude da tradicional "linguagem de Tratado". São utilizados modelos verbais que induzem mais à configuração de normas sem aplicabilidade imediata, assemelháveis a soluções de compromisso político ${ }^{32}$.

Sublinhe-se que tais caracaterísticas não impediram nem detiveram a atuação comunitária. o que gerou inúmeros choques (seja no relacionamento com os Estados-membros, seja no próprio âmbito interno comunitário).

\section{VIII.6) Classificação de competências}

De regra, costumam-se classificar as competências dos Estados federados em exclusivas (ou da união ou dos estados) e concorrentes. Eventualmente, alude-se a competência supletiva. Essa sistematização até pode ser utilizada a propósito da UE. mas não será muito satisfatória, como se inferirá da exposiçāo abaixo. Mais interessante é aquela proposta por DENYS SIMON ${ }^{33}$, que indica cinco categorias de competências nacionais, a saber: a) abolidas; b) transferidas; c) delimitadas ${ }^{34}$; d) coordenadas; e) reservadas.

As competências abolidas envolvem poderes a que os Estados renunciaram para participar da UE. Trata-se de competências extintas e, rigorosamente, nem seria o caso de aludir-se a elas. Afinal, seu desaparecimento acarreta impossibilidade lógica de sua inclusão no elenco das competências existentes. Mas a referência é interessante e útil, por permitir compreender os limites impostos aos Estados-membros. Tais poderes suprimidos se encontravam especialmente no âmbito de disciplina aduaneira, tributação e regulação do tráfego de mercadorias. Nenhuma regra poderá ser editada nesses campos, quer pela UE, quer pelos Estados-membros.

Quanto às competências transferidas, os Estados-membros deixaram de dispor de qualquer poder, repassando-as à titularidade privativa e exclusiva da UE. Isso não significa, como ressalta DENYS, que a competência atribuída à UE seja necessariamente idêntica àquela titularizada anteriormente pelo Estado-membro. Em mui-

32 Considere-se, por exemplo, o art. 140 do TCE, assim redigido: "Visando a realizar os objetivos previstos no art. 136 e sem prejuízo de outras disposiçōes do presente tratado, a Comissão encorajará a cooperaçāo entre os Estados membros e facilitará a coordenação da ação deles em todos os domínios da política social relevante do presente capítulo e notadamente nas seguintes matérias: ao emprego; ao direito do trabalho e às condições de trabalho; à formação e ao aperfeiçoamento profissional; à seguridade social; à proteção contra os acidentes e as moléstias profissionais; à higiene do trabalho; ao direito sindical e às negociações coletivas entre empregadores e empregados. Para tanto, a Comissão agirá em contato estreito com os Estados membros, através de estudos, de avisos e através da organização de consultas, tanto para os problemas que se ponham no plano nacional como aqueles que se relacionem às organizações internacionais. Antes de emitir os avisos previstos no presente artigo, a Comissão consultará o Comitê econômico e social".

33 Le système juridique communautaire, Paris. PUF, 1998, 2ª ed.. p. 73 e ss.

i4 A expressāo francesa é "encadrées", mas não parece que a tradução por "enquadradas" seja satisfatória. 
tos casos, há limitações a ser respeitadas pela UE que não existiam quando a titularidade era dos Estados-membros.

As competências delimitadas envolvem poderes mantidos pelos Estados-membros, mas afetados seriamente em virtude da participação na UE. Seu exercício pelo Estado-membro não pode prejudicar a realização dos fins inerentes à Comunidade e se sujeita aos provimentos comunitários destinados à harmonização das legislações domésticas. Assim se passa, por exemplo, no campo de licitações. Cada Estadomembro é titular do poder de legislar sobre contratação administrativa, mas há o dever de adotar leis compatíveis com regras fixadas pela UE. Respeitados esses limites, os Estados são livres para adotar a disciplina que reputarem mais adequada. Como assinala SYMON, não se trata de uma hipótese de comunhão de competências entre UE e Estados-membros. Há competências de diversas naturezas, qualitativamente distintas entre si. No Brasil, talvez se pudesse estabelecer algum paralelo com o art. 24 da $\mathrm{CF} / 88$, que reconhece à União poder de editar normas gerais, cabendo aos Estados adotarem as específicas. Mas os dois casos não são idênticos, eis que a competência para editar "normas gerais" prevista na legislação brasileira é muito mais ampla do que a reservada à Comunidade nos casos de competências delimitadas.

As competências coordenadas se caracterizam pela competência da UE para adotar medidas vinculantes acerca do processo de produção, mas não quanto ao conteúdo, de atos dos Estados-membros. O exercício do poder do Estado-membro sujeita-se a uma espécie de requisito procedimental, destinado a assegurar atuação integrada com os demais Estados. Essa modalidade é comumente imposta para as competências no âmbito do segundo e terceiro pilares. Trata-se de alternativa muito próxima àquela praticada no relacionamento entre Estados soberanos, em que não se restringe o poder decisório no tocante à matéria, mas se impõe um dever de consulta prévia.

Por fim, as competências reservadas são aquelas que estão fora dos efeitos do Direito Comunitário. Aí se incluem, em primeiro lugar, os poderes atinentes a temas não relacionados a temas comunitários. Mas também estão compreendidas competências que foram objeto de reserva por ocasião da assinatura dos Tratados ou da adesão à $\mathrm{UE}^{35}$ e as que, teoricamente enquadráveis no âmbito comunitário, foram explicitamente remetidas à competência interna por regra geral do próprio Tratado.

Essa classificação se refere às competências nacionais em face da UE, o que retrata uma específica abordagem da questão e uma tomada de posição até mesmo ideológica. A classificação se funda claramente numa visão interna ao Estado-membro e é produzida pela comparação entre os momentos anterior e posterior à participação na União. Há a reafirmação de que, em origem, todas as competências eram nacionais. Além disso, a abordagem é interessante porque permite apreender uma das peculiaridades da UE, que não é resultado da simples "transposição" de competências nacionais. Não existe apenas modificação no aspecto subjetivo da titularidade, mas há alteração qualitativa da competência. A instauração da UE gerou variação qualitativa de cada ordem jurídica interna: o fenômeno não se identifica à

35 Variáveis, portanto, de Estado-membro para Estado-membro. 
redução (quantitativa) de poderes, mas à mutação (qualitativa) das diferentes ordens jurídicas nacionais. Esse é um dos fatores que impedem considerar a UE como modalidade de mera soma de Estados soberanos.

Note-se que a classificação evidencia uma espécie de reação à existência de competências próprias da UE, o que equivaleria a concordar com sua natureza supranacional, meio caminho para reconhecer-lhe condição de Estado soberano. Portanto, considerar todas as competências sob o ponto de vista do Estado-membro evitar reconhecer soberania à UE e permite compreender a situação jurídica dos Estados-membros sem necessidade de determinar a natureza jurídica da $\mathrm{UE}^{36}$.

\section{VIII.7) Subsidiariedade e princípios fundamentais sobre competência}

Os Tratados de Amsterdã deram grande destaque ao princípio da subsidiariedade como instrumento de regulação da partilha de competência entre UE e Estados-membros. Há referência específica a ele no art. art. $5^{\circ}$ do $\mathrm{TCE}^{37}$, o que não deve conduzir a esquecer que o princípio permeia os Tratados em sua integralidade ${ }^{38}$.

$\mathrm{O}$ art. $5^{2}$ contém três núcleos normativos. O primeiro limita a atuação da Comunidade, que não poderá extravasar as competências recebidas e os objetivos a ela fixados (princípio da limitação da competência comunitária). O segundo estabelece que, se houver competências comuns, a intervenção comunitária dependerá de configurar-se como via de realização mais satisfatória dos objetivos visados (princípio da subsidiariedade). $O$ terceiro refere-se à atuação o menos restritiva possível por parte da Comunidade (princípio da proporcionalidade). Ademais, foi adotado Protocolo específico acerca dos princípios da subsidiariedade e da proporcionalidade, em que se explicita mais minuciosamente o conteúdo semântico dessas cláusulas e os fins que norteiam sua aplicação ${ }^{39}$.

36 Não é casual que classificação tenha sido produzida pela doutrina francesa, cuja cultura é extremamente refratária à modificação da identidade nacional. Esse é um dos (muitos) paradoxos da UE: sua instituição se deveu aos esforços franceses, sem os quais nunca teriam nascido as comunidades. Mas precisamente a França têm produzido, ao longo do tempo, as significativas reaçōes à unificação. Sobre o tema, analisando as (perversamente) reais motivações que orientavam França e Alemanha por ocasião da instauração da UE, vale a pena consultar ALAN S. MILWARD, History and Theory, em The European Rescue of the nation State, London, Routledge, 1992, p. 17. 37 A redação do dispositivo é a seguinte: "A Comunidade atuará nos limites dos poderes que lhe sāo conferidos e dos objetivos que lhe são atribuidos pelo presente Tratado. Nos domínios que não sejam das suas atribuiçōes exclusivas, a Comunidade deverá atuar, de acordo com o princípio da subsidiariedade, apenas se e na medda em que os objetivos da ação proposta não puderem ser suficientemente atingidos pelos Estados-membros, e puderem, em virtude da dimensāo ou dos efeitos da ação prevista, ser melhor alcançados através da Comunidade. Qualquer ação comunitária deve não exceder o necessário para atingir os objetivos deste Tratado.

38 GRÁINNE DE BÚRKA, The Principle of Subsidiarity and The Court of Justice as Institutional Actor, Journal of Common Market Studies, vol. 36, n² 2, June 1998, p. 219.

39 O Protocolo referido é muito extenso para ser aqui transcrito, mas merece leitura e análise. Por outro lado, far-se-á referência apenas à subsidiariedade, sem exame da proporcionalidade. Isso 
a) A subsidiariedade como solução política

As inovações propostas por ocasião dos Tratados de Maastricht (especialmente a substituição do critério da unanimidade pelo da maioria) despertaram forte oposição dos Estados-membros. A subsidiariedade foi a alternativa para superar o impasse, especialmente após a rejeição pela Dinamarca ao Tratado. A solução foi ardorosamente defendida por Reino Unido e Alemanha. É muito possível que, sem a consagração do princípio da subsidiariedade, não tivesse sido viável a implantação da UE.

Isso não significa ser o conceito de subsidariedade preciso ou determinado ${ }^{40}$. Seu núcleo consiste na afirmação de que, em havendo competência comuns entre Estados-membros e UE, esta somente atuará quando a atuação nacional não puder realizar satisfatoriamente os fins buscados. A relevância da regra é evidente, diante da impossibilidade de afirmar a absoluta ausência de competência da UE. Sempre será possível, no mais diferentes campos, reconhecer alguma manifestação de interesse comunitário. Essa era a razão do desconforto dos Estados-membros com a simples previsão de que a UE somente poderia atuar nos campos de competência própria: afinal, a experiência evidenciara crescente e contínua ampliação da intervenção comunitária.

\section{b) Um limite flexível para a competência comunitária}

$O$ conceito de subsidiariedade não era novo ou desconhecido no âmbito europeu. Suas origens são reportáveis à Encíclica Quadragésimo Ano e os partidos democratas cristãos eram seu ardorosos defensores. O princípio já vigia no Direito alemão, eis que o art. 72. 20 da Lei Fundamental estabelecia que, no âmbito de competências concorrentes com os Länder, a Federação tinha "o direito de legislar sempre que $e$ enquanto exista a necessidade de uma regulação legislativa federal porque assim o requeiram a criação de condições de vida equivalentes no território federal ou a manutenção da unidade jurídica ou econômica no interesse da totalidade do Estado"4l. Mas a aplicar o princípio para discriminar competências da UE importa complexidades muito mais significativas. Afinal, a natureza dos poderes detidos pela UE em face dos Estados-membros não pode ser determinada com segurança. É impossível comparar a relação interna mantida entre pessoas políticas de uma $\mathrm{Fe}$ deração àquela vigente na dimensão comunitária.

A discriminação de competências fundada na subsidiariedade, tal como prevista para a UE, envolve uma espécie de "duplicidade" de limites. Para cada tema,

deriva não apenas da ausência de pertinência da temática da proporcionalidade à análise aqui desenvolvida como do acolhimento da proposta de DE BURCA, no sentido de que o princípio da proporcionalidade pode ser englobado no da subsidiariedade (The Principle of Subsidiarity..., cit., p. 220). Tal proposta, se questionável em termos amplos, pode ser aceita no estrito âmbito da discussão enfrentada no texto.

40 Aliás, foi precisamente essa indeterminação do conceito é que propiciou a harmonização de diferentes posiçōes nacionais.

41 Conforme ANTONIO ESTELLA DE NORIEGA, La Paradoja de la Subsidiariedad: reflexiones en torno a la jurisprudencia comunitaria relativa ao artículo $3 B(2)$ del Tratado de la Comunidad Europea, Civitas Revista Española de Derecho Administrativo, 101, enero-marzo 1999, p. 74. 
impõe-se uma limitação geral, sintetizável no postulado de que a UE somente dispõe de competência para realizar os fins comunitários ${ }^{42}$. A subsidiariedade é uma segunda delimitação da competência. Segundo o Protocolo, "A subsidiariedade constitui-se num conceito dinâmico que deve ser aplicado à luz dos objetivos enunciados no Tratado. Permite alargar a ação da Comunidade, dentro dos limites das suas competências, se as circunstâncias o exigirem e, inversamente, limitar ou pôr termo a essa ação quando ela deixar de justificar-se".

Ou seja, respeitados os limites máximos da competência, há um critério interno de sua redução ${ }^{43}$. Talvez se pudesse aludir à existência de aspectos "abstratos" e "concretos" da competência. O primeiro é enunciado pelos Tratados. O segundo resulta do exame da situação real e da aplicação do princípio da subsidiariedade. $O$ resultado é a flexibilidade da competência comunitária, que pode estender-se até os lindes fixados no Tratado ou ser restringida para menos. A solução escapa aos padrões usuais de partilha de competência, norteados por pretensão de rigorismo e rigidez. A idéia de uma competência mutável, cujos limites dependemdo caso concreto, rompe com a tradição dos esquemas de partilha de poder. Inviabiliza formulações abstratas apriorísticas, que pretendam formular soluções gerais para o futuro. Mais precisamente, trata-se de regra jurídica que se reporta a critério claramente extralegal. A solução jurídica não se funda em postulados meramente lógicos, consgrados em regra legal abstrata. A interpretação-aplicação da norma de competência depende de circunstâncias externas ao plano legislativo e é incompatível com generalizações absolutas.

Sob um ângulo, a solução é semelhante à das normas em branco, de há muito conhecidas no âmbito do Direito Penal. Ademais disso, poderia argumentar-se que a norma jurídica sempre remete o aplicador ao universo circundante. Mas o caso apresenta diferença marcante. Todas as consideraçōes acima referidas foram formuladas a propósito das normas de conduta, não quanto às de competência ${ }^{44}$. Reputa-se que os requisitos de validade e a delimitação dos poderes políticos para decidir fazem-se ao interno da ordem jurídica, de modo fixo e rígido. Portanto, admite-se sem dificuldade que o conteúdo da regulação de condutas depende de uma avaliação fático-axiológica ou de circunstâncias externas à norma, mas a titularidade do poder decisório deve determinar-se por via normativa. A solução comunitária rompe com essa tradição e remete a fixação da competência à avaliação de fatores extranormativos.

42 Insista-se em que os Tratados fixam soluções distintas para cada tema, atribuindo à UE poder de atuação mais ou menos limitado, de acordo com as circunstâncias.

43 Essa fórmula permite algum questionamento, eis que pressupõe duas teses questionáveis. A primeira é a possibilidade prática de determinar "limites máximos" para a competência comunitária. A segunda é a ausência de expansão da competência comunitária. Rigorosamente, nenhuma das duas teses é procedente.

44 Essa peculiaridade poderia ser apontada mesmo a propósito do pensamento kelseniano. Quando afirma que toda norma é uma moldura a ser preenchida no momento da aplicação, a teoria purista acolhe a idéia de rigidez da moldura - em última análise, a moldura rígida é a competência para decidir. 


\section{c) Requisitos}

O Protocolo sobre o princípio da subsidiariedade buscou estabelecer critérios mais precisos para solução dos casos concretos, enunciando três requisitos para legitimar a atuação comunitária. São eles a pertinência, a necessidade e a eficiência.

A pertinência significa que a atuação comunitária depende da existência de aspectos transnacionais, que ultrapassem os limites dos interesses exclusivamente nacionais.

A necessidade corresponde à impossibilidade de omissão. $O$ requisito está presente quando evidenciado que a questão exige atuação de ente político em vista do risco de sacrifício de valores e interesses reputados relevantes e protegidos pelos Tratados. Indica o dever de algum ente político desenvolver ação para realizar tarefas indispensáveis.

Por eficiência, indica-se a exigiência de que a ação desenvolvida no nível comunitário revele-se como mais vantajosa, mais satisfatória do que aquela desempenhada no nível estatal.

Sob o prisma lógico, o dois primeiros requisitos não integram o conceito próprio de subsidiariedade. A pertinência identifica-se com o limite externo da competência comunitária, enquanto a subsidiariedade se configura como um limite interno. É óbvio que o limite interno está contido no externo. Somente se pode cogitar de aplicar a subsidiariedade após verificar a existência de uma competência da UE. Portanto, a pertinência pode até ser um pressuposto da verificação da subsidiariedade, mas com ela não se confunde. A explícita referência a pertinência pode ser justificada pelo temor da utilização da subsidiariedade como instrumento de ampliação do limite externo da competência comunitária. Já a necessidade não é via de diferenciação entre órbitas de poder, mas explicita característica das circunstâncias do mundo exterior. A necessidade aponta para o dever de um sujeito atuar, mas não permite identificar o sujeito competente. Talvez fosse possível reputar que a necessidade é pressuposto negativo de competência da UE: ausente ela, veda-se atuação comunitária, o que não impede que o Estado-membro opte por atender aquele interesse. Então, seria reservado aos Estados o campo das atuações não necessárias. Mas a validade do raciocínio é duvidosa porque a relevância dos efeitos sobre a vida comunitária acarretará atuação isolada do Estado-membro, ainda em matérias destituídas de "necessidade". Ou seja, não basta a ausência de necessidade para caracterizar a competência nacional.

O núcleo do conceito de subsidiariedade reside na eficiência. A determinação da titularidade da competência, em questões de interesse comum, depende da avaliação da eficiência. A órbita política que estiver em condições de adotar a solução mais satisfatória, sob o ponto de vista concreto, será titular da competência jurídica para atuar. Então, no campo das competências comuns é impossível fixar regra abstrata acerca de competências, mas se impõe o dever de examinar as circunstâncias do caso concreto e verificar aspectos não apenas jurídicos, mas políticos, econômicos e sociais. Isso não significa ser a eficiência simples relação de cunho econômico (custo-benefício). Não se define a competência a partir somente da avaliação econômica dos custos envolvidos. Intepreta-se a expressão "eficiência" em acepção ampla, indicando dever de selecionar a alternativa que importe a realização mais 
rápida, menos desgastante para os interesses individuais e nacionais e mais conforme com os valores éticos envolvidos ${ }^{45}$. Diante de diferentes possibilidades teóricas, será obrigatório optar por aquela que se configurar como a mais eficiente - apenas que. no caso, as "possibilidades teóricas" consistem em diferentes esferas de competência. A discriminação da competência se funda na disponibilidade de instrumentos para melhor e mais satisfatória execução de certos objetivos, entre os quais está certamente o de "unificação européia" mas não apenas ele. Em última análise, a consagração da subsidiariedade correspondeu à juridicização do princípio da eficiên$\mathrm{cia}^{46}$. Essa opção apresenta algumas virtudes notáveis, que não podem deixar de ser destacadas.

Dissociar poderes entre duas órbitas políticas sempre produz insatisfações, traumas e seqüelas. A divisão de competências no âmbito comunitário poderia ter-se feito através de critérios políticos, o que envolveria disputas árduas e, provavelmente, destinadas ao fracasso. Os Tratados de Maastricht modificaram a própria natureza da decisão. A adoção do princípio da subsidiariedade alterou a forma de enfrentar o problema da discriminação de competências, substituindo os critérios políticos pelos técnicos. Não se questiona quem tem "direito" de dispor sobre certa temática. Aliás, nem se fixa quem "poder abstrato" para tanto. A questão se resolve em determinar quem dispõe dos melhores instrumentos, da maior capacitação, da atuação mais proveitosa. Produziu-se uma forma de "neutralização" das controvérsias políticas, impedindo discussões acerca do passado, de tradições nacionais e de rompimento com manifestações culturais históricas. Além de tudo, a fórmula da subsidiariedade não produz soluções imutáveis, já que a modificação das circunstâncias pode propiciar alternativas distintas ao longo do tempo.

Adotar a subsidiariedade significa entronizar critérios de decisão discutíveis segundo regras racionais e objetivos. A disputa pelo poder político passa a desenvolver-se no campo do conhecimento, da técnica e da ciência. Será vencedora a órbita política titular de maior habilidade para vencer as dificuldades materiais e realizar melhor o interesse comum dos diferentes povos. Em última análise, a órbita política "derrotada" deverá imputar o resultado à própria incapacidade de satisfazer certos interesses. Ou seja, a solução não poderá ser atacada como "injusta". Além disso, haverá um certo "consolo" pela perspectiva de que serão implantadas as melhores soluções, aquelas mais eficientes, de modo que todos serão beneficiados. A construção é acompanhada de argumento não vocalizado de que a atribuição da competência à órbita menos eficiente representaria, na verdade, a frustração do interesse público e individual. Dar acolhimento a uma órbita ineficiente corresponderia a adotar decisão moral e politicamente indefensável. Poderiam lembrar-se as

45 Sob esse ângulo, o próprio princípio da proporcionalidade poderia ser reconduzido ao conceito de subsidiariedade.

46 Nesse sentido e por toda a doutrina, consultem-se KEES VAM KERSBERGEN e BERTJAN VERBEEK, The Politics of Subsidiarity in the European Union, Journal of Common Market Studies, vol. 32, n² 2, June 1994. especialmente às pp. 221 e ss. 
palavras de CHEVALIER, acerca da evolução do Direito nos dias atuais, em que "a efetividade torna-se a condição e a garantia de sua legitimidade" 47 .

Esse diagnóstico não significa valoração da subsidiariedade como critério de competência. Apresenta aspectos positivos, propiciando a superação de disputas políticas sempre indesejáveis. Também envolve ângulos negativos, o principal dos quais consiste na transformação do universo político-jurídico em um mundo regido por cálculos de custo-benefício. Quando se prioriza o princípio da eficiência, é muito problemático impedir que os raciocínios meramente econômicos se superponham a considerações de outra ordem. Relação custo-benefício, em sentido próprio, configura-se quando se consideram fatores econômicos, eis que valores não patrimoniais inadmitem comparação objetiva. Enfim, é difícil fazer prevalecer alternativa claramente ineficiente do ponto de vista econômico sob argumento de ser a mais adequada do ponto de vista axiológico ou cultural.

Ressalte-se que o tema não se identifica com a polêmica surgida na doutrina brasileira a propósito da modificação do art. 37 da $\mathrm{CF} / 88$ pela $\mathrm{EC} \mathrm{n}^{\mathrm{0}} 19 . \mathrm{O}$ princípio da eficiência passou a ser referido neste dispositivo como instrumento de controle da atividade administrativa. A alteração do texto retrata a consagração de teoria já há muito defendida pela melhor doutrina, que sustentava que a discricionariedade não retratava uma liberação política da atividade administrativa, mas o "dever-poder" de escolher a solução mais adequada em face da realização do interesse público. A melhor vocalização desse entendimento deve-se, sem margem de dúvida, a CELSO ANTÔNIO BANDEIRA DE MELLO ${ }^{48}$. Diversa é a problemática em face do Direito Comunitário, eis que o princípio da eficiência é o critério jurídico de identificação da competência de diferentes órbitas políticas. Ainda assim, há um contexto subjacente comum a ambas as discussões: a patrimonialização dos critérios de validade dos atos jurídicos.

\section{IX - Estruturação formal da administração comunitária e a partilha de competências}

A estruturação da UE envolve um grande número de servidores e de órgãos (comitês, comissões). Mas há quatro órgãos principais ${ }^{49}$, em que se concentram os poderes mais relevantes, a saber a Comissão, o Conselho, a Corte de Justiça e o Parlamento ${ }^{50}$. Ressalte-se que essa não é a versão organizacional original. Na origem,

47 Vers un Droit Post-Moderne? Les Transformations de la Régulation Juridique, Revue du Droit Public, Mai-Juin 1998, p. 680.

48 Confira-se os indispensáveis apontamentos em Discricionariedade e Controle Jurisdicional, S. Paulo, Malheiros, 1992.

49 Poder-se-ia acrescentar a Corte de Contas, mas as funções desse órgāo são basicamente de controle interno. Portanto e para os fins do presente estudo, não se aludirá a esse órgão.

so Reitere-se, ainda que com algum excesso, que essa configuração não corresponde a alguma fórmula de tripartição de poderes de origem tradicional. 
havia um triângulo institucional de maior relevância. que envolvia os três primeiros órgãos. A evolução histórica comunitária conduziu à configuração atual e nada impede que outras mutações venham a ocorrer.

\section{IX.1) $O(s)$ Conselho(s)}

O Conselho ${ }^{51}$ é formado por um representante de cada Estado-membro e tem sede em Bruxelas (ainda que algumas de suas sessões se realizem em Luxemburgo). É importante destacar a possibilidade de variação na sua composição. Somente podem participar do Conselho agentes nacionais com "nivel ministerial" — ou seja, devem integrar formalmente a estrutura de poder político do Estado-membro, em condições de representar seu país. Admite-se que um Estado delegue poderes ao representante de outro Estado para atuação no Conselho. ${ }^{52}$ É possível que o Conselho se reúna em nível de chefes do Poder Executivo (o que conduz à caracterização do chamado "Conselho Europeu") tanto como em nível de ministros de áreas específicas, se houver uma certa peculiaridade na matéria a ser discutida. Não se consideram as pessoas físicas como membro do Conselho: a titularidade da participação é do Estado-membro, a ser exercida por seus agentes. Isso possibilita, inclusive, que diferentes "composições" funcionem, mesmo concomitantemente. Isso permitiu a configuração, até o presente, de pelo menos 20 formações diferentes para o Conse1 ho ${ }^{53}$.

O Conselho delibera coletivamente. Cada Estado é titular de um certo número de $\operatorname{votos}^{54}$. No total, são 87 votos. Há três modalidades de quorum de deliberação: unanimidade, maioria qualificada e maioria simples. Para fins de maioria qualificada, o art. 205, 2, fixou em 26 votos a minoria de bloqueio. A regra propicia diferentes combinaçōes de interesses, em que concessões recíprocas podem (devem) ser efetuadas para aprovação ou rejeição de propostas. Em vista do número de votos de que dispõem, a posição conjunta de três dentre cinco países (Alemanha, Espanha, França, Inglaterra e Itália) é suficiente para impedir aprovação de proposta sujeita a maioria qualificada.

O Conselho é presidido pelo representante de um dos Estados-membros, com mandato de seis meses, em rodízio. A condição de presidente do Conselho é extremamente relevante, eis que a ele incumbe definir a pauta das questōes a ser debatida,

51 Sua disciplina consta dos arts. 202 a 210 do TCE.

52 Confira-se em JEAN-LOUIS QUERMONNE, Le système politique de l'Union européenne, .... Montechrestien, 1998, $3^{2}$ ed., p. 40.

53 Assim, por exemplo: composiçāo em nível de Chefes do Executivo, de Ministros de Finanças, de Ministros de Agricultura etc..

54 Segundo o art. 205, 2, a distribuição de votos é a seguinte: Bélgica - 5, Dinamarca - 3 . Alemanha - 10, Grécia - 5, Espanha - 8. França - 10. Irlanda - 3, Itália - 10, Luxemburgo - 2. Holanda -5 , Áustria -4 , Portugal -5 . Finlândia -3 , Suécia -4 , Inglaterra -10 . 
iniciar a discussão dos temas pertinentes, enfim. selecionar as matérias que o Conselho avaliará no universo de suas competências.

O Conselho é assessorado por um secretariado geral que dispõe de aproximadamente 2.500 servidores. Ademais disso, existe um Comitê de Representantes Permanentes (COREPER), que exerce funções especiais de assessoramento e de execução de deliberações do Conselho. Este Comitê vem assumindo crescentes atribuições.

A competência do Conselho será examinada mais abaixo, eis que é adequado um exame conjunto com aquela atribuída à Comissão.

\section{IX.2) A Comissäo}

A Comissão $0^{\varsigma \varsigma}$ é composta de vinte ${ }^{\varsigma \hbar}$ membros, nacionais de um dos países da UE. Cada Estado deverá ter pelo menos um e no máximo dois nacionais compondo a Comissão (TCE, art. 213, 1). É-lhes assegurada independência e vedado exercício de qualquer outra atividade profissional, mesmo não remunerada. $O$ mandato é de cinco anos, admitida recondução. O procedimento de designação é complexo. Os Estados-membros escolhem, de comum acordo, o Presidente da Comissão, escolha que é submetida ao Parlamento. Em seguida, os Estados-membros, em concerto com o Presidente, designam os outros membros da Comissão. Existem dois procedimentos de destituição (em sentido amplo). Há hipótese de responsabilização pessoal por infração a deveres jurídicos, em que há deliberação da Corte de Justiça, com cunho punitivo (TCE, art. 213,3). Mas há possibilidade de destituição coletiva, em virtude de moção de censura aprovada pela maioria do Parlamento. ${ }^{57}$

A Comissão delibera por maioria de votos. Mas cada comissário recebe atribuição de atuação em determinado setor, de modo a incumbir-lhe trazer ao conhecimento da Comissão os assuntos pertinentes à sua área. Existem algumas competências que podem ser exercitadas individualmente pelo membro da Comissão responsável pelo setor. Algumas hipóteses de grande importância se dão no campo da concorrência econômica, em que a autonomia individual do membro da Comissão é bastante significativa.

A Comissão se sedia em Bruxelas e é assessorada por aproximadamente 20.000 servidores permanentes ${ }^{58}$, alguns dos quais sediados em Luxemburgo. Mas um número muito maior de pessoas, integradas ou não nas burocracias nacionais, é chamado a colaborar com ela, na condição de especialistas, assessores eventuais etc.. ${ }^{59}$

55 Sua disciplina consta dos arts. 211 a 219 do TCE.

56 Número que pode ser modificado pelo Conselho, atuando à unanimidade (TCE, art. $213, \S 2^{2}$ ).

57 O quorum é peculiar: maioria de dois terços dos presentes, desde que isso corresponda à maioria absoluta do Parlamento.

s8 Dos quais um terço é composto de tradutores, e a maioria dos atos é traduzida para todas essas línguas.

59 Difundiu-se a expressāo "comitologia" para indicar essa característica da atividade através de 
O Parlamento europeu ${ }^{611}$ é composto por 625 membros, indicados pelos Estados-membros, segundo procedimentos eleitorais próprios ${ }^{61}$. O Parlamento se sedia em Estrasburgo, mas parte de sua estrutura é estabelecida em Luxemburgo e suas sessões suplementares se realizam em Bruxelas. O mandado parlamentar é de cinco anos, admitindo-se a cumulação com mandato eletivo em parlamento local (mas não com o desempenho de outras funções públicas ou comunitárias). As funções do Parlamento vêm sendo ampliadas ao longo dos diferentes Tratados. Detinha competência meramente consultativa ao início. Atualmente, é titular também de certo poder de emenda e de veto suspensivo, além de competência de fiscalização da atuação da Comissão. Dispõe de poderes para aprovar o orçamento da Comunidade, ainda que em atividade conjugada com o Conselho e a Comissão.

\section{IX.4) As competências de Conselho, Comissão e Parlamento}

Para compreender as competências de Conselho, Comissão e Parlamento ${ }^{62}$, deve ter-se em vista que não existe separação rigorosa de funções executivas e legislativas $^{63}$ no âmbito da UE. Um mesmo órgão acumula competências executivas e legislativas e o Parlamento não é o preponderante titular da função legiferante.

Originariamente, a Comissão detinha o monopólio do poder de iniciativa, o que foi sendo mitigado ao longo dos diferentes Tratados. De todo o modo, a maior parte dos poderes de impulsão é de sua titularidade. Mas não lhe incumbe competência para deliberação, a qual é atribuída ao Conselho. Este delibera em virtude de iniciativa exercitada (basicamente) pela Comissão, mas lhe é facultado modificar projetos, desde que por unanimidade. O Conselho concentra a maior parcela das competências normativas, incumbindo ao Parlamento, em alguns casos, função de co-deliberação. O Conselho também exerce funções executivas, especialmente no plano de relações exteriores. É-lhe facultado delegar à Comissão poderes de execução das deliberações que adotar.

"comitês", cuja profusão quantitativa e mutiplicidade qualitativa impede maiores sistematizações. Somente poucos funcionários especializados dominam a mecânica desse funcionamento.

60 Disciplinado nos arts. 137 a 144.

61 Segundo o art. 190, a distribuição das cadeiras é a seguinte: Alemanha - 99; França, ReinoUnido e Itália - 87; Espanha - 64; Holanda - 31; Bélgica, Grécia e Portugal - 25; Suécia 22; Áustria - 21; Dinamarca e Finlândia - 16; Irlanda - 15; Luxemburgo - 6.

62 O Parlamento possui escassas competências no plano legislativo e sua competência é muito mais de cunho fiscalizatório, como se verá adiante.

63 A própria Corte chegou a afirmar que "Sob a sistema de que governa os poderes da Comunidade, os poderes das instituiçôes e as condiçōes acerca de seu exercício derivam de várias previsões específicas do Tratado e as diferenças entre essas previsōes, particularmente no que se refere à participaçāo do Parlamento Europeu, são nem sempre baseadas em critérios consistentes" (Caso 242/87, [1989] ECR-1.426). 
Observe-se que os poderes do Conselho são muito mais intensos no âmbito do segundo e do terceiro pilares (por motivos mais do que evidentes). A atuação da Comissão, nos campos da CFSP e da CJHA, é irrisória, sendo muito mais ampla no tocante às Comunidades.

A Comissão é também dotada de um poder de defesa dos Tratados, incumbindo-lhe uma espécie de "fiscalização" sobre os Estados-membros, no que se assemelha a uma agência ${ }^{64}$ de defesa dos princípios comunitários. Ademais, inúmeros dispositivos específicos atribuem competências pontuais para a Comissão, envolvendo não apenas tarefas meramente "executivas" mas também normativas.

Existem diferentes modalidades procedimentais de decisão, no âmbito da Comunidade, em que variam os poderes de cada entidade. Como explica JEAN-LOUIS QUERMONNE, é mais adequado aludir a um sistema de governo e de administração "em rede" do que a uma sistemática de separação de poderes. ${ }^{65}$

\section{IX.5) A Corte de Justiça das Comunidades Européias - CJCE}

A Corte de Justiça ${ }^{66}$ é integrada por quinze juízes, escolhidos de comum acordo pelos governos dos Estados-membros, com judicatura por seis anos, admitida a recondução. Tem sede (assim como o Tribunal de Primeira Instância) em Luxemburgo e sua competência genérica é "assegurar o respeito do Direito pela interpretação e aplicação do presente tratado" (art. 220). Em princípio, incumbe à Corte pronunciar-se acerca de litígios envolvendo a infração ao Direito Comunitário.

A competência da Corte de Justiça deve ser diferenciada em vista do objeto. Quando se questionam atos provenientes de órgãos comunitários, prevê-se um "controle de legalidade" (TCE, art. 173) envolvendo exame dos requisitos de competência, forma, compatibilidade com os Tratados ou outras regras jurídicas e desvio de poder $^{67}$. Nessas hipóteses, a legitimidade ativa é atribuída a Estado-membro, Conselho e Comissão. Também são dotados de legitimidade ativa o Parlamento, a Corte de Contas e o Banco Central Europeu, desde que em defesa de suas próprias competências. Quando os órgãos comunitários produzirem atos de aplicação concreta em relação a determinada pessoa privada (física ou jurídica), surge para elas a possibilidade de exercitar direito de ação equivalente ao antes referido. Portanto e como regra, não é cabível um particular insurgir-se contra atos praticados por órgãos

64 A utilização do vocábulo não é casual.

65 Le système politique de l'Union européenne, cit, p. 33.

66 Disciplinada nos arts. 220 a 245.

67 A CJCE rejeita a possibilidade de controle dos atos comunitários pelas justiças locais. Mais precisamente, admite que a validade dos atos comunitários seja pronunciada pela jurisdição nacional, mas interdita-lhe a possibilidade de decretar a invalidade. Sobre o tema, confira-se DENYS SIMON, Le Système Juridique Communautaire, Paris, PUF, 1998, 2a ed., p. 502. 
comunitários, a não ser quando diretamente dirigidos contra eles ou se aptos a produzir efeitos específicos na sua órbita jurídica própria ${ }^{\mathrm{k}}$.

Sendo julgado procedente o pedido, a Corte de Justiça emite provimento de natureza constitutiva negativa, declarando nulo e inexistente ( $n u l$ et non avenu, é a fórmula textual do art. 231) o ato impugnado. A peculiaridade é o prazo de dois meses para exercício do direito de ação ${ }^{69}$. Mas há possibilidade de provimentos condenatórios dos órgãos comunitários a agir, em caso de omissão incompatível com o Direito Comunitário (art. 232). Não se prevêem provimentos constitutivos positivos, em que a decisão produziria efeitos equivalentes às do ato omitido.

$\mathrm{O}$ art. 233 ressalva a possibilidade de aplicação cumulativa com o disposto no art. 288, que trata da responsabilidade contratual e extracontratual do Comunidade ${ }^{70}$, o que significa que a desconstituição do ato inválido ou condenação da Comunidade a agir não eliminam o direito de indenização por eventuais perdas e danos.

Outra é a situação quando a ação ou omissão ofensiva ao Direito Comunitário é imputada a Estado-membro. Lembre-se que a Comissão exerce função de defensora do Direito Comunitário e é a principal legitimada para impugnar a atuação dos Estados-membros. Mas não é a única titular dessa legitimidade. Os Estados-membros são beneficiados por uma espécie de legimitação extraordinária. Verificada ofensa a seus interesses por ato imputável a outro Estado, incumbe-lhes provocar a Comissão, titular da legitimação ativa. Se essa permanecer inerte, os Estados poderão (decorridos três meses) exercitar o direito de ação em nome próprio. Como regra, um particular não pode iniciar demanda diretamente em face da Corte, mesmo alegando ofensa por Estado-membro a seus direitos próprios.

$\mathrm{Na}$ formulação do art. 228 do TCE, a Corte de Justiça não tem competência constitutiva (positiva ou negativa) quanto a atos dos Estados-membros. Reconhecida a infração, a Corte emite um provimento de cunho mandamental ${ }^{71}$. Aliás, competência dessa natureza foi utilizada na famosa causa da "Guerra dos Morangos". A França deixou de adotar providências materiais para assegurar o livre ingresso e comercialização de produtos agrícolas estrangeiros, permitindo a atuação sistemática de uma organização chamada Coordination Rurale. As forças policiais francesas presenciaram a destruição dos produtos, sem adotar providências adequadas. A

68 Sob um certo ângulo, acolhe-se a distinção entre interesse legítimo e direito subjetivo, restringindo a legimitidade ativa aos casos de ofensa a direito subjetivo.

69 É problemático definir se o prazo é prescricional ou decadencial, especialmente tendo em vista que essa distinção não é compatível com o ordenamento jurídico de todos os países da UE.

70 A regra do art. 228, segunda parte, é muito peculiar. Vale transcrever o texto: "Em matéria de responsabilidade nāo contratual, a Comunidade deverá reparar, conformemente aos principios gerais comuns aos direitos dos Estados-membros, os danos causados por suas instituições ou por seus agentes no exercicio de suas funçōes". O art. 235 estabelece que a Corte de Justiça será competente para processar e julgar açōes de indenização fundadas no art. 288.

71 Rigorosamente, a Corte não "determina" ao Estado que faça ou deixe de fazer algo, até mesmo pela ausência de algum vínculo jurídico de superposição. Mas o art. 228, 1, fixa que o Estado-membro é "obrigado" a adotar as medidas que a decisão da Corte comporte. Idêntica é a redação do art. 233. 
Comissão invocou a tutela da Corte. Em dezembro de 1997, declarou-se que a França tinha infringido os deveres impostos pelos Tratados ${ }^{72}$.

Recusando-se o Estado-membro a corrigir a violação, a Comissão poderá produzir uma espécie de "ação de execução" 73 em face da Corte de Justiça. Nesse caso, a Comissão pleiteará a condenação do Estado-membro recalcitrante ao pagamento de uma indenização ou uma multa cominatória (astreinte).

Ademais, está prevista manifestação da Corte sobre a interpretação do Direito Comunitário, no curso de processos perante a jurisdição dos Estados-membros. $\mathrm{O}$ art. 234 prevê o dever de qualquer órgão jurisdicional nacional pleitear à Corte manifestação incidental acerca da validade de atos normativos locais em face do Direito Comunitário. Essa regra envolve tema de grande relevância, pois foi através dessa via que a Corte produziu modificação qualitativa da ordem jurídica comunitária. Sobre o tema, voltar-se-á adiante.

É necessário lembrar do disposto no art. 243 do TCE, que autoriza a Corte a prescrever as medidas cautelares ("provisoires") necessárias.

Essas são as competências principais da Corte, mas há outras, dispersas ao longo dos Tratados, de menor relevância (ao menos, em termos estatísticos).

Assinale-se que a sistemática acima exposta não se aplica a atos praticados no âmbito do segundo e do terceiro pilar. O sumário acima efetuado refere-se aos atos praticados no campo das Comunidades ${ }^{74}$. Isso fica claro na disposição do art. 46 do TUE, que estabelece regra exaustiva da competência da Corte. Não se autorizou controle sobre atos enquadrados no segundo pilar. Admitiu-se que a Corte de Justiça poderá atuar limitadamente no tocante ao terceiro pilar.

Para concluir esse breve sumário, deve destacar-se a existência de um Tribunal de Primeira Instância, previsto no art. 225, ao qual são atribuídas competências delimitadas, por decisão do Conselho (por proposta da Corte e após ouvidos Comissão e Parlamento). Não é possível atribuir a esse Tribunal competência para apreciar as questões prejudiciais referidas no art. 234 (em essência, controle in concreto de compatibilidade dos atos nacionais com a legislação supranacional).

\section{$\mathrm{X}$ - Competências privativas da UE e harmonização de tendências opostas}

Existe teoria da separação dos poderes típica da UE, destinada a evitar a preponderância absoluta e definitiva de uma determinada órbita de poder. A organização da UE busca realizar dois fins igualmente relevantes. O primeiro é impedir

72 Caso C-265/95, [1997] ECR I-6969/7006.

73 A qualificação talvez seja excessiva em face do direito brasileiro, eis que nāo se tratará propriamente de execução compulsória do conteúdo da decisão emitida no processo anterior.

74 Talvez não tenha sido mera casualidade nem força da tradição a manutenção da denominação do órgão (Corte de Justiça das Comunidades Européias), como que ressaltando que sua atividade se desenvolvia no âmbito do primeiro pilar. 
que um Estado-membro capture a estrutura da UE ou faça preponderar seus interesses sobre os demais, ainda que através do mecanismo de obstrução. $O$ segundo reside em obstar que a UE se transforme em um organismo estatal na acepção própria do termo, impondo-se como sujeito autônomo em face dos Estados-membros.

Ou seja, configuram-se dois objetivos antitéticos e que, em última análise, seriam entre si excludentes. Como se passa em todas as uniões entre Estados, a UE envolve duas forças dinâmicas de orientação contraposta, uma identificável como "nacionalista" e outra como "supranacionalista". A primeira se traduz na tendência centrífuga de fortalecimento dos Estados-membros. A última configura-se como vocação centrípeta de gerar um núcleo de poder consistente, eliminando a autonomia local. O método comunitário promove uma forma especial de compor essas duas tendências inconciliáveis, fundando-se na concepção de que o fortalecimento do supranacionalismo deve fazer-se pela via da modificação do nacionalismo, antes do que às custas de sua supressão. Ou seja, a UE aspira não à eliminação do nacionalismo, mas à sua alteração. Também nesse sentido é que se alude a um "construtivismo" europeu, para indicar a fermentação de novas e mais profundas identidades supranacionais. A proposta é incompatível com a imposição de um modelo pronto e acabado de Estado supranacional, nem se se coaduna com o sacrifício puro e simples das peculiaridades locais. Logo, a estruturação político-jurídica da UE é norteada por filosofia que exige grande sensibilidade política: fortalecimento da União e manutenção das autonomias locais, simultânea e conjuntamente. Ao longo dos últimos cinqüenta anos, o empreendimento vem sendo desenvolvido com sucesso, talvez em virtude de estruturação político-jurídica muito sofisticada, apto a harmonizar as diferentes tendências ${ }^{75}$. Em suma, a existência de competências privativas da UE não indica necessária preponderância da orientação supranacionalista, eis que o sistema é dotado de instrumentos de garantia às orientações opostas.

Por outro lado, insista-se em que a teoria da separação de poderes internos da UE não se reporta à concepção de Montesquieu. Não se trata de evitar que as funções de administrar, produzir leis e aplicá-las a casos concretos sejam acumuladas por um mesmo órgão. A pluralidade de estruturas orgânicas, exercendo diferentes funções, relaciona-se mais propriamente à realização equilibrada das duas tendências acima referidas.

\section{$\mathrm{XI}$ - Nacionalismo e supranacionalismo na estruturação da UE}

Como visto, a estruturação da UE se relaciona diretamente com essa concepção de equilíbrio. Alguns órgãos são caracteristicamente "nacionalistas", enquanto ou-

75 É óbvio que o trecho acima não atribui o sucesso até agora vivenciado pela UE apenas ao modelo de estruturação jurídica. Existem inúmeros outros fatores relevantes, entre os quais avultam o sucesso econômico (os Estados europeus apresentam fortalecimento econômico extraordinário, ainda que alguns índices evidenciem sérios problemas) e o ideológico (geração de um sentimento de comunhão que fortalece a individualidade). 
tros são marcadamente "supranacionalistas". Na primeira categoria, está o Conselho. Em princípio, também o Parlamento tende a adotar posições dessa ordem. Já a Comissão e a Corte de Justiça estão no outro grupo.

A distinção deriva da autonomia da atuação do órgão em relação aos Estadosmembros. É evidente que todos os órgãos comunitários dispõem de idêntica autonomia formal. Mas é possível diferenciar a intensidade da vinculação dos membros do órgão comunitário relativamente ao Estado-membro, inclusive sob o ponto de vista do título a que exercem suas funções. Sob esse ponto de vista, os membros do Conselho são, em última análise, representantes dos Estados-nacionais. Assim se passa por não desempenharem funções comunitárias sob título próprio. Atuam como porta-vozes dos respectivos Estados. Por exemplo, não existe mandato de integrante do Conselho, mas essa é condição derivada do desempenho de função no Estadomembro. Assim, o Chefe do Executivo é automaticamente membro do Conselho Europeu. Cessada sua investidura na função nacional, extingue-se automaticamente sua participação no órgão.

Já em outros casos, o indivíduo detém título próprio, com mandato a prazo certo, para integrar o órgão comunitário. A Comissão e a Corte de Justiça têm sua autonomia assegurada pela desvinculação de seus membros das estruturas governamentais locais. Ainda que a indicação dependa da concordância do Estado-membro, isso não produz para ele vínculo de representatividade (nem permanente nem formal). Como decorrência, os membros da Comissão e da Corte de Justiça não têm o dever de prestar contas de seus atos ao Estado de origem nem é possível cogitar-se de ingerência formal dos governos nacionais sobre a atividade dos membros desses órgãos.

A situação do Parlamento é híbrida. Seus membros são titulares de mandatos eletivos em nome próprio e não estão sujeitos a qualquer dependência em face dos governos locais. No entanto, a natureza do mandato eletivo importa a representatividade dos interesses locais. Portanto, a situação dos parlamentares é inconfundível com a dos membros da Comissão e da Corte de Justiça. Espera-se que os parlamentares vocalizem os interesses nacionais na dimensão européia. ${ }^{76}$ Portanto, é muito mais adequado classificar o Parlamento na categoria de órgão com tendência nacionalista do que na outra. Aliás, essa incerteza pode explicar a pequena relevância das suas atribuições antes dos Tratados de Amsterdã. Considerado aquele órgão como uma espécie de "caixa de percussão" da opinião pública, seria um grande risco atribuir-lhe poderes mais significativos enquanto não ficasse definidade a posição das populações nacionais. Tanto é verdade que a ampliação das competências parlamentares coincidiu com a afirmação da opinião pública européia a favor da consolidação do projeto comunitário ${ }^{77}$. Isso não significa, nem de longe, que o

76 Tendência incrementada pela ausência de partidos políticos de dimensāo supranacional.

77 Essa tendência manifestou-se ao longo dos últimos cinco anos. Mesmo à época de Maastricht, as populaçōes locais não estavam conectadas mais fortemente à idéia comunitária. 
Parlamento europeu desempenhe funçōes equivalentes às reservadas, nas diferentes ordens internas, as respectivos órgãos parlamentares.

As complexas fórmulas procedimentais e os critérios heterodoxos de discriminação de competência são orientados a assegurar o equilíbrio entre órgãos nacionalistas e supranacionalistas ${ }^{78}$. Mas é evidente que a tendência supranacionalista recebe tratamento especial, pois a construção da Europa unificada é o fim último a ser atingido. Isso fica claro com a concentração do poder de iniciativa em mãos da Comissão, fazendo presumir que somente serão desencadeados projetos orientados à realização dos interesses supranacionais, nunca o oposto. Até é possível que tais projetos não venham a ser aprovados, mas não serão formuladas propostas em sentido favorável às orientações nacionalistas. ${ }^{79}$

É interessante observar que os instrumentos de proteção à corrente nacionalista acabam fortalecendo igualmente a orientação oposta. Isso decorre de que a oposição ao supranacionalismo depende de atuação conjunta e harmônica dos Estados-membros. Logo, a oposição a propostas dos órgãos de orientação supranacionalista acarreta a formação de um bloco "nacionalista". Essa atuação harmônica dos Estados-membros amplia a concepção de "solidariedade fática" em que se fundamenta o projeto de unificação européia.

\section{XII - Consolidação e expansão do Direito Comunitário pela atuação da CJCE}

A implantação do projeto comunitário desenvolveu-se não apenas através da atuação dos órgãos propriamente políticos (Conselho e Comissão). Fez especialmente pela atividade do único órgão cuja competência é, por assim dizer, homogênea e exclusiva: a Corte de Justiça. Lembre-se que os demais órgãos comunitários foram estruturados com competências conjugadas e interdependentes, sendo impossível sua atuação isolada. Diversamente se passa com a Corte, que é integrada por juízes autônomos e decide sem interferência externa. ${ }^{80}$

78 Também esse é o princípio que disciplina a dinâmica da UE, de modo que decisōes arrojadas em direção ao supranacionalismo tendem a ser seguidas de retrocessos que prestigiem as concepções nacionalistas.

79 Apercebendo-se disso, os Estados-membros ampliaram o poder de iniciativa de outros órgãos e estabeleceram que qualquer projeto submetido ao Conselho poderia ser integralmente alterado por voto unânime. Fixou-se, porém, que a Comissão dispunha do poder de retirar o projeto a qualquer tempo, desde que ainda não aprovado pelo Conselho. Em termos práticos, isso significa que a Comissão pode retirar o projeto no curso da votação do Conselho, desde que verificada unanimidade que possa desvirtuar determinada proposta.

80 É evidente que toda decisão de "formato jurisdicional" retrata circunstâncias político-ideológicas e vivências subjacentes - a obviedade da asserção dispensa maiores considerações. No entanto. a formulação de uma decisão jurisdicional não se sujeita à circunstância imediata e direta do condicionamento político. 
Através de sucessivas decisões, a Corte de Justiça produziu uma organização político-jurídica para a Comunidade, que não estava prevista formalmente nos Tratados.

A primeira decisão fundamental foi proferida em 1963 (caso 26/62, conhecido como "van Gend en Loos"). Tratou-se de conflito surgido na Holanda, acerca de imposto sobre importação de produto da Alemanha. Um tribunal local levantou a necessidade de manifestação da Corte de Justiça, que enunciou princípios que se tornaram alicerce da concepção comunitária. O julgado estabeleceu que "[A] Comunidade constitui uma nova ordem legal de direito internacional em benefício da qual os Estados restringiram seus direitos de soberania, ainda que dentro de campos limitados, e que abrange não apenas os Estados-membros mas também seus nacionais. Em decorrência, independentemente da legislação dos Estados-membros, a lei da Comunidade não apenas impõe obrigações sobre os particulares mas também está autorizada a conferir-lhes direitos que se tornam parte de seu patrimônio jurídico ("legal heritage"). Esses direitos surgem näo apenas quando expressamente atribuidos pelo Tratado, mas também em virtude das obrigações que o Tratado impõe de modo claramente definido sobre os particulares tanto quanto sobre os Estados-membros e as instituições da Comunidade"8!.

O julgado van Gend en Loos firmou o postulado do efeito direto do Direito Comunitário em face das ordens jurídicas locais. Isso significa, por um lado, desnecessidade formal de acolhimento das regras dos Tratados pelas ordens jurídicas nacionais. As regras comunitárias fundamentais incorporam-se automaticamente aos Direitos nacionais. Por outro lado, as regras comunitárias (excluídas as diretivas, cuja situação é peculiar e será adiante exposta) podem ser invocadas diretamente por parte dos cidadãos e têm de ser respeitadas pelos órgãos nacionais.

A segunda causa relevante foi Costa v. Enel, julgado em 1964 (Case 6/64). O litígio surgiu porque o Ente Nazionale Energia Elettrica (Enel) italiano foi beneficiado por decreto de nacionalização da produção e distribuição de energia elétrica. Um particular (Flamínio Costa), invocando a condição de sócio minoritário de sociedade nacionalizada e de consumidor de energia elétrica, impugnou os atos governamentais. $\mathrm{O}$ juiz conciliador reconheceu a necessidade de manifestação da Corte de Justiça. O governo italiano levantou preliminares de grande relevância, entre as quais a de que juiz italiano era obrigado a aplicar o Direito nacional. A Corte rejeitou esses argumentos e asseverou que "os principios fundamentais gerados pelo Tratado, uma fonte independente de direito, não poderiam, em virtude de sua especial e original natureza, ser afastados por previsões legais domésticas, ainda que formalmente existentes, sem que isso importasse serem eles destituidos de seu caráter de lei comunitária e sem que os próprios fundamentos legais da Comunidade fossem colocados em questão" ${ }^{2}$. O julgado adotou a concepção de que

81 [1963] ECR 12.

82 [1964] ECR 594. 
os Estados-membros tinham realizado uma transferência de poderes para "o sistema legal comunitário" $\$ 3$, cuja consequiência era a invalidade de qualquer ato unilateral incompatível com as regras comunitárias. No caso Costa v. Enel, ficou assentado o princípio da supremacia hierárquica do Direito Comunitário sobre o direito nacional. Deve ressaltar-se, no entanto, que a Corte se negou a interpretar o direito local e não pronunciou vício de regras nacionais incompatíveis com a ordem comunitária. Essa posição é mantida até o momento atual. Interpreta-se e aplica-se o Direito Comunitário, remetendo à jurisdição interna exame da validade do Direito local. É óbvio que avaliar infração ao Direito Comunitário demanda examinar o Direito local em profundidade - tarefa que, ainda que realizada, é formalmente negada pela Corte.

Outra decisão importante foi proferida no caso Simmenthal (Case 106/77, decidido em 1978). Empresa italiana importava carne da França. O governo italiano determinou submissão do produto a inspeções sanitárias, incumbindo ao importador o custo dos exames. Iniciado o processo perante a Justiça italiana, a Corte foi provocada para interpretar o Direito Comunitário. O governo italiano implicitamente reconheceu o defeito das regras impugnadas, mas sustentou necessidade de esgotar-se o procedimento em face de sua própria jurisdição. Argumentou que invalidade do direito italiano teria de ser apreciada, em primeiro lugar, pela Corte Constitucional italiana e, somente depois e se fosse o caso, pela Corte de Justiça ${ }^{84}$ No caso, destacou-se a característica (comum, de resto, aos sistemas jurisdicionais europeus) de o controle de constitucionalidade ser concentrado, vedando-se aos órgãos judiciários deixar de aplicar um dispositivo sob fundamento de sua invalidade. A Corte rejeitou as preliminares, estatuindo que "[U]ma corte nacional a quem se demanda, dentro dos limites de sua jurisdição, aplicar previsões do Direito Comunitário está sob o dever de dar pleno efeito a essas previsões, se necessário recusando-se de oficio (of its own motion) a aplicar qualquer previsão conflitante da legislação nacional, mesmo se adotada posteriormente, e não se faz necessário à corte requisitar ou aguardar a prévia desconstituição de tais previsões pelo Legislativo ou outra via constitucional" ${ }^{85}$.

Aí se completa a concepção de que o Direito Comunitário é hierarquicamente superior ao direito nacional (nas áreas de competência própria), tem aplicação direta e imediata e deve ser aplicado de ofício pelas cortes locais, independentemente do grau de jurisdição. Em última análise, assim se delineia a concepção da unidade do ordenamento jurídico europeu, em que regras de âmbito comunitário e de compe-

83 É interessante observar que, à época, a Corte não se sentiu à vontade para afirmar que haveria um novo sujeito, beneficiário da transferência de poderes. Na redação textual do julgado, preferiu-se fórmula de objetivar o Direito Comunitário, tal como se fosse um sujeito com existência própria. Aliás e como se verá adiante, essa é uma fórmula muito propícia ao desenvolvimento de concepções filosóficas institucionalistas.

84 Vale transcrever um trecho da argumentação: "qualquer conflito entre a regra nacional e as previsões comunitárias tem de ser eliminadas através dos meios disponíveis no âmbito dos sistemas legais nacionais".

85 [1978]ECR 646. 
tência nacional se integram em um único corpo harmônico, funcionando os juízes nacionais como órgãos de aplicação do Direito Comunitário.

Inúmeras outras decisões reforçaram aspectos complementares dessa concepção. Assim, em diferentes oportunidades a Corte estabeleceu que dificuldades políticas internas de um determinado Estado-membro não eram suficientes para justificar a ausência de adoção de diretivas emitidas pelos órgãos comunitários ${ }^{86}$. No julgado Defrenne v. Sabena, a Corte fixou que princípios fundamentais consagrados nos Tratados deviam ser respeitado não apenas pelo órgãos estatais nacionais mas pelos próprios particulares entre si ${ }^{87}$ Essas concepções foram incrementadas por julgados específicos acerca de diretivas (tema ao qual se voltará adiante).

Além disso, a Corte de Justiça firmou o princípio da perempção, pelo qual a assunção de certa competência pela Comunidade, elimina o poder dos Estados-membros sobre a matéria, mesmo a título de colmatação de lacunas ${ }^{88}$.

\section{XII.2) A “constitucionalização" do Direito Comunitário}

Ao assentar essas orientações, a Corte de Justiça estabeleceu as bases de um sistema harmônico e unitário, em que os Estados-membros são vinculados ao Direito Comunitário. O tema tem merecido seguidas análises da doutrina (além de propiciar polêmicas calorosas na vida política), mas vale referir as considerações de G. FEDERICO MANCINI, desenvolvidas enquanto juiz integrante da Corte ${ }^{89}$. Afirmou que 'a Corte tem produzido a 'constitucionalização' do Tratado, isto é, modelar uma estrutura constitutional para uma estrutura de configuração federal na Europa. Se esse esforço foi sempre inspirado por uma filosofia clara e consistente é algo a ser indagado, mas não é realmente importante. O que realmente importa são suas conquistas - e elas são evidentes para todos" 90 .

A constitucionalização consistiu na transformação da própria natureza da Comunidade, por via de modificação da força vinculante dos Tratados. Sob um certo ângulo, poderia dizer-se que se passou de um sistema tipicamente dualista (que

86 Nesse sentido, houve decisão no Caso $91 / 79$ (conhecido como "Detergentes"), em [1980] ECR 1099-1113.

87 Caso 43/75. No julgado se lê: “39. De fato, desde que o artigo 119 é mandatório por natureza, a proibiçāo de discriminação entre homens e mulheres aplica-se não apenas à ação das autoridades públicas, mas também se estende a todos os acordos destinados a regular condiçōes coletivas de trabalho, como também a contratos individuais" ([1976]ECR 476).

88 Seguindo essa linha, confira-se a seguinte passagem: "Sempre que a Comunidade tiver incluido em seus atos legislativos internos previsões relativas ao tratamento de nacionais de países nāo membros ou expressamente outorgado a suas instituições poderes para negociar com países não membros, ela adquirirá exclusiva competência externa nas esferas cobertas por esses atos" (Opiniāo 1/94, [1994] ECR I-5274). Confira-se, ainda, JOSEPH WEILER, The Constitution of Europe, cit., p. 23.

89 The Making of a Constitution for Europe, Common Market Law Review 26:595-614(1989).

90 Ob. cit., p. 596. 
depende da recepção através de legislação interna das regras contidas em tratados internacionais) a um sistema unitário. Mas a asserção é parcialmente incorreta e bastante incompleta. $E$ incorreta porque algumas regras comunitárias somente se integram no Direito interno através de sua consagração através de ato nacional formal (como se verá adiante). A incompletude deriva de que o fenômeno foi muito mais complexo, porque se traduziu na integração da Corte de Justiça e das magistraturas nacionais em um sistema unitário de aplicação do Direito Comunitário ${ }^{y 1}$. Ressalte-se que, na visão da Corte, a diferenciação entre "sistemas dualistas e não dualistas" não faz muita diferença. Ainda que alguns atos normativos comunitários dependam de consagração por parte das ordens nacionais, isso não significa que sua natureza seja equivalente à de um tratado.

Comparando o estágio atual das estruturas comunitárias com as perspectivas previstas originalmente, é espantosa a dimensão da obra realizada pela Corte. Isso tem conduzido a doutrina a examinar os fatores que tinham permitido à Corte realizar tamanhas inovações. MANCINI acatava a tese de que a CJCE tinha sido favorecida pela localização em um local como Luxemburgo, afastado das luzes da imprensa, a que se somavam juízes largamente experientes, dotados de grande sabedoria, com autoridade pessoal em face da comunidade jurídica internacional. Acima de tudo, porém, sublinhava o apoio recebido da Comissão e dos tribunais nacionais.

Examinando as ponderações de MANCINI, é compreensível o respaldo da Comissão. Como visto, ambos os órgãos compartilham orientação "supranacionalista”. Mas é intrigante a posição adotada pelos magistrados dos Estados-membros. Antes de tudo, sublinhe-se que a adesão dos tribunais nacionais foi fundamental para o sucesso das inovações implementadas pela Corte, que não dispunha de meios próprios para fazer prevalecer suas decisões. Por outro lado, os Executivos e Legislativos nacionais não estavam dispostos a admitir redução de seu próprio poder. A adesão (espontânea) das magistraturas nacionais era a única via para a Corte (e a própria Comunidade) obter aceitação de sua jurisprudência. A questão que remanesce é o motivo pelo qual magistraturas dos diferentes Estados europeus prestaram obediência a um órgão externo, de natureza supranacional. Algumas especulações podem ser feitas.

Sem dúvida, a autoridade pessoal dos juízes da Corte foi relevante. Mas é difícil admitir que tanto teria bastado para a adesão das magistraturas nacionais. Outras causas podem ser cogitadas. Assim, observe-se que grande parte das provocações à atuação da Corte de Justiça proveio não dos órgãos da magistratura de último grau. Pode significar que o sistema consagrado nos Tratados permitiu a liberação da

91 WEILER descreve essa concepção nos seguintes termos: "A tese constitucionalista pretende que, em aspectos críticos, a Comunidade evoluiu e se comporta como se seu instrumento de fundação não fosse um tratado governado pelo Direito Internacional mas, para usar a linguagem da Corte Européia de Justiça, uma carta constitucional governada segundo as formas do Direito Constitucional" (The Reformation of European Constitutionalism, Joumal of Common Market Studies, vol. 35, $\mathrm{n}^{2}$ 1, March 1997, p. 97). Sobre o mesmo tema, consulte-se ALEC STONE SWEET, The European Court and National Courts - Doctrin and Jurisprudenc, org. por ANNE-MARRIE SLAUGHTER et alii, Oxford, Hart Publishing, 1998, p. 306 e ss. 
magistratura a quo de laços (inclusive políticos, mas também jurídicos) que as constrangiam no âmbito dos Estados-membros. Provocar a manifestação da Corte de Justiça representava a superação de estrutura de poder tradicional, até então utilizada pelos órgãos de cúpula nacionais para condicionar todos os membros do sistema. Sob esse ângulo, a ausência de instrumentos de controle difuso e in concreto no âmbito dos diferentes Estados-membros teria sido fator fundamental para motivar a magistratura de primeiro grau a aderir às novas regras. A vedação do exame da constitucionalidade das leis constrangia os julgadores de grau inferior de jurisdição a aplicar o Direito ainda quando o reputassem defeituoso. Nesse contexto, provocar a Corte de Justiça configurava-se como instrumento para contornar a submissão ao esquema de poder político-jurídico vigente no sistema nacional. Lembre-se que a jurisprudência da Corte impôs o dever de todo e qualquer juiz recusar aplicação do Direito local incompatível com o sistema comunitário. Isso produziu significativa ampliação do poder da magistratura de hierarquia funcional inferior. Como exemplo emblemático, recorde-se o Caso Simmenthal, acima referido, em que a República da Itália negava a magistrado de primeiro grau o poder de deixar de aplicar regra evidentemente inválida. O núcleo da disputa, então, não era a compatibilidade da regra nacional com o Direito Comunitário. O problema estava na possibilidade de juiz de primeiro grau eximir-se dos esquemas de poder vigorantes na Itália.

Pode apontar-se outro motivo, relacionado ao primeiro. A jurisprudência da Corte de Justiça representou também o fortalecimento geral dos Poderes Judiciários nacionais. Não é possível restringir o enfoque e afirmar simplesmente que a Corte de Justiça ampliou seu próprio poder. As inovações produzidas pela intervenção da Corte produziram acréscimo de poder não apenas para ela, mas também para as magistraturas nacionais em face dos demais órgãos políticos internos. A relação entre Corte de Justiça, como órgão supranacional, e magistraturas, como órgãos nacionais, foi bilateral e complementar. Não se processou somente o fortalecimento de um dos pólos dessa relação, mas de ambos. Ou seja, a jurisprudência da Corte de Justiça afetou não apenas os órgãos de menor hierarquia dos judiciários nacionais. Foi muito mais ampla, pois assegurou oposição, controle e físcalização pelos magistrados nacionais em relação à atividade desenvolvida pelos demais poderes. A partilha interna de poderes, no âmbito de cada Estado nacional, foi alterada em virtude da orientação jurisprudencial comandada pela Corte de Justiça.

Mas o sucesso alcançado pela Corte pode ser creditado também a outro fato, relacionado a circunstâncias externas aos Judiciários locais. A comunitarização envolvia modificação radical da distribuição de poder econômico. As decisões da Corte de Justiça, impondo a prevalência do Direito Comunitário, orientaram-se à supressão de privilégios e vantagens injustificados, de origem meramente política ou caracterizáveis como abusivos. Todos os sujeitos e agentes econômicos em situação de privilégio (obviamente uma minoria) viram-se desafiados pela "europeização". Logo, a crítica à Comunidade foi identificada com a defesa da manutenção de privilégios. A maioria da população voltou-se contra a minoria de privilegiados - o que significou apoiar as propostas de implantação da Comunidade. Talvez esse tenha sido o maior aliado da Corte: o apoio das populações dos Estados-membros que passaram a recorrer ao Judiciário como forma mais eficaz para eliminar privi- 
légios cujo combate era impossível fazer-se através da sistemática político-jurídica até então existente. A descrença das populações nos Parlamentos e nos Executivos produziu a quebra de sua legitimidade como "guardiões" dos valores nacionais e, ao mesmo tempo, o incremento da legitimidade dos órgãos comunitários. A Comunidade passou a ser a esperança de realização das bandeiras de igualdade, da fraternidade e da solidariedade, tão profundamente desgastadas por décadas de frustração no âmbito dos Estados-nacionais. Nessa linha, pode-se enquadrar o famoso caso Cassis de Dijon. Empresa alemã pretendia importar produtos alcoólicos da França. Apesar de autorizada a importação, o governo alemão vedou a comercialização dos produtos importados porque o teor alcoólico mínimo admissível na Alemanha, para licores de vinho, era de $30 \%$ e o produto importado apresentava apenas $15 \%$ de gradação alcoólica. O importador recorreu à Corte de Justiça, que reconheceu a invalidade da regra alemã, sob pressuposto de que produtos regularmente fabricados em qualquer país da Comunidade podiam ser livremente comercializados no âmbito comunitário. ${ }^{92}$ A Corte de Justiça serviu como instrumento para afastar regras nacionais destituídas de razoabilidade, resultantes de práticas políticas rejeitadas pela população. Sem qualquer demérito aos Judiciários locais, pode afirmar-se que a Corte de Justiça passou a ser visualizada como órgão rigorosamente imparcial e um bastião da defesa dos postulados da igualdade.

Aliás, em uma passagem interessante e que somente poderia adquirir pleno sentido algumas décadas após, a Corte referiu-se a esse ângulo do problema, ao julgar van Gend en Loos $^{93}$.

Nada prova, porém, a correção de todas essas teses. Sem qualquer laivo de cinismo, é possível que o êxito da Corte tenha sido produzido na esteira do sucesso da Comunidade. Sob essa perspectiva, o fator mais significativo pode ter sido o sucesso (macro-)econômico. Os Estados integrantes da UE vêm obtendo êxitos econômicos relevantes. Ainda existindo dificuldades marcantes no âmbito do desemprego, as empresas européias floresceram. A atividade econômica privada apresentou grande progresso, em períodos relativamente curtos de tempo. Se o êxito econômico não foi a maior de todas as causas, sua ocorrência permite compreender a natureza dos fatos. É inquestionável que uma situação de fragilidade econômica e insucesso empresarial teriam conduzido ao esfacelamento do projeto da unificação européia.

\section{XII.3) Restrições passadas, presentes e futuras à atuação da CJCE}

Seria equivocado imaginar que as inovações produzidas pela Corte foram acolhidas sem qualquer oposição. Assim não o foi, especialmente no plano político.

92 Caso 120/78, ECR [1979] 649-673.

93 "A vigilância dos particulares preocupados em proteger seus direitos conduz a uma efetiva supervisão em acréscimo à supervisão prevista pelos Artigos 169 e 170 à diligência da Comissão e dos Estados-membros" (ECR-13). 
Lembre-se que, em meados da década de 60 , verificou-se uma das maiores crises da Comunidade. É muito possível que tivesse sido fomentada também pela verificação da tendência de supremacia do Direito Comunitário sobre os Direitos nacionais. Compôs-se o problema através do Acordo de Luxemburgo, que substituiu o quorum de maioria para as decisões do Conselho pelo critério da unanimidade. A solução acalmou os Estados-membros e evitou confrontações imediatas. Ou seja, se os Estados-membros podiam determinar o conteúdo do Direito Comunitário (em virtude do quorum de unanimidade), deixava de ser problemática a prevalência dele sobre os Direitos nacionais ${ }^{94}$.

Por outro lado, não deve supor-se inocorrência de oposição das Cortes nacionais à intervenção da CJCE. Inúmeras manifestações ocorreram, ao longo do tempo, contra a tendência expansionista da Corte. Alguns desses aspectos serão abaixo referidos, especialmente no tocante à defesa das regras constitucionais nacionais. Ainda que, grosso modo, a Corte tenha mantido sua autoridade intata, sempre houve desafios às concepções por ela desenvolvidas.

Quanto ao futuro, podem prever-se desafios mais intensos por parte dos juízes nacionais, caso a Corte de Justiça decida manter algum tipo de atividade expansionista. O limite de expansão do Direito Comunitário por via jurisprudencial foi atingido. É que outras expansões ulteriores significarão invasão de temas peculiarmente nacionais, o que produzirá reações intensas. Até porque qualquer ampliação envolverá os institutos de Direito Privado e, como chega a afirmar-se, "o direito privado representa o coração do Estado nacional, no direito privado se reflete a identidade cultural de uma Nação" 95 . Ou seja, as diferentes Nações não estão dispostas, neste momento, a aceitar intervenções externas mais intensas.

\section{XIII — O problema da dimensão meramente "econômica" da Comunidade}

O Tratado de Roma objetivava gerar uma união econômica, em que se assegurassem as "quatro liberdades" no âmbito dos Estados-membros: liberdade de deslocamento de pessoas, de serviços, de capital e de bens ${ }^{96}$. Todos os assuntos "internos" estavam fora do âmbito da Comunidade, como também aquilo que se relacionasse com outros direitos e garantias individuais ${ }^{97}$. Não havia (como ainda não há)

94 Nesse sentido, WEILER defendeu que "Os Estados-membros sentiram-se menos ameaçados pela constitucionalização porque eles tomaram controle do processo decisional através do veto de fato previsto no Acordo de Luxemburgo" (Journey to an Unknown Destination: A Retrospective and Prospective of the European Court of Justicein the Arena of Political Integration, Journal of Common Market Studies, vol. 31, $n^{2} 4$, December 1993, p. 430).

95 HANS-W. MICKLITZ, Prospettive di un diritto privato europeo: ius commune praeter legem?, artigo publicado em Contratto e Impresa/Europa, Cedam, 1999, 1, p. 45.

96 "De fato, a atividade da Comissão na área de política social e regulação social foi bastante modesta no período entre 1958 e o fim dos anos setenta, com uma notável exceção: política de meio-ambiente" (GIANDOMENICO MAJONE, The European Community between Social Policy and Social Regulation, Journal of Common Market Studies, vol. 31, $\mathrm{n}^{\mathbb{2}}$ 2, June 1993, p. 154). 
uma "declaração de direitos fundamentais", no âmbito do Direito Comunitário. A história da UE é a resenha da ampliação desses limites. Em perspectiva vertical. submeteram-se aos efeitos da lei comunitária temas inicialmente vislumbrados como meramente internos, tal como exposto acima. Sob dimensão horizontal, a comunidade passou a abranger outros temas de natureza não econômica.

\section{XIII.1) Impossibilidade de tutela restrita a Direitos Econômicos}

A ampla e ilimitada tutela aos direitos de cunho econômico conduziu a impasse. A proteção exclusiva da liberdade econômica pode fazer-se sem maior dificuldade até certo ponto ${ }^{98}$. Como é evidente, as liberdades econômicas são apenas uma das manifestações de princípios fundamentais. Mas não é possível tutelar parcialmente Direitos Humanos, cuja natureza é complexa e infracionável. Assegurar tutela e proteção apenas a liberdades econômicas põe em risco a Democracia, porque realização integral e exclusiva apenas delas significa a supressão de outras manifestações de Direitos Fundamentais. Esse é o campo de colisões de direitos, em que diferentes manifestações de liberdades se contrapõem. A temática é muito conhecida do Direito Constitucional, que convive com a aparente contradição entre direitos e garantias e a necessidade de superar tais conflitos. Seria possível manter a Comunidade com abordagem exclusivamente econômica na medida em que existissem somente interesses de natureza econômica. É usual a natureza heterogênea dos direitos e garantias a considerar em uma situação conflitiva.

\section{XIII.2) $A$ intervenção da Corte}

Após etapa inicial de afirmação dos princípios de conotação econômica, a vida comunitária começou a presenciar conflitos entre liberdades de diversa natureza. Em face dessa situação, existiam três alternativas para a Comunidade.

A primeira consistia em adotar posição "ortodoxa conservadora". Isso significaria afirmar supremacia da liberdade econômica, reputando inválida qualquer disposição nacional que, para tutelar Direitos Humanos, restringissem Direito Econômicos. Nesse caso, a Comunidade afastaria outros Direitos Humanos sempre que pudessem produzir algum limite à livre circulação de mercadorias, à ausência de discriminação entre pessoas ou produtos etc. As decorrências político-ideológicas dessa concepção ordem são evidentes. Estar-se-ia diante da afirmação do capitalismo mais selvagem (mais ainda do que aquele ora vigente).

97 Lembre-se que mesmo o direito de locomoção somente foi assegurado como instrumento de liberdade de atividade econômica. Não havia regra assegurando a liberdade de ir e vir em si mesma. Não por acaso, o tema teve de ser objeto de outras avenças, no âmbito de Schengen.

98 Nesse sentido, GIANDOMENICO MAJONE, The European Community between, cit., p. 168. 
A segunda opção poderia chamar-se "ortodoxa moderada". Traduzir-se-ia no reconhecimento de que o conflito entre Direitos Humanos e Direitos Econômicos escaparia ao âmbito da Comunidade. Portanto, não seria possível judicar como inválida a restrição à liberdade econômica por disposição nacional orientada à tutela de Direitos de outra ordem. Remeter-se-ia a análise da colisão de direitos às cortes nacionais. Como decorrência, cada Estado-membro consagraria soluções distintas para problemas semelhantes, inviabilizando-se uniformidade na interpretação das regras propriamente comunitárias (de natureza econômica).

A terceira alternativa era a "heterodoxa", configurada na expansão dos limites da Comunidade. Reconhecer-se-ia que o Direito Comunitário abrangia não apenas as liberdades econômicas mas todas as demais que pudessem a elas relacionar-se. Os órgãos comunitários teriam de examinar as questões supranacionais não apenas sob a estrita óptica econômica, mas também tendo em vista os demais direitos e garantias. Logo, a competência da Comunidade teria de ser ampliada.

Em suma, era impossível manter ordem comunitária de natureza exclusivamente econômica, a não ser destruindo e eliminando os Direitos de natureza não econômica que com aqueles conflitassem. Ressalva dessa ordem somente é imaginável no plano da teoria, eis que concretamente impraticável. Seria impossível faticamente compelir os Estados-membros a dispensar um um acervo democrático irremediavelmente integrado em suas ordens político-sociais. Orientação da Comunidade na direção da primeira alternativa (ortodoxia conservadora) produziria reação incontível dos Estados-membros e a revolta de grandes parcelas das populações locais.

Também a segunda opção não apresentava condições de ser adotada. Não seria possível cada Estado-membro consagrar regras distintas acerca dos limites da liberdade econômica ou sobre o significado e extensão de direitos e garantias que delimitam as atividades econômicas. A opção da ortodoxia moderada representava a autodestruição da Comunidade.

Em última análise, a única via aberta para sobrevivência da Comunidade era deixar de ser uma ordem exclusivamente econômica. Em termos mais amplos, essa postura era inevitável também para manter a legitimidade do projeto comunitário. A recusa em acrescentar a proteção aos Direitos fundamentais restringiria a aprovação que a Comunidade vinha obtendo crescentemente das mais diferentes instâncias nacionais. Nas palavras de WEILAR, “... mesmo se a proteção dos direitos humanos de per si não precisa ser indispensável para a modelação de uma constituição de tipo federal, isso era crítico para obter aceitação pelos cortes dos Estados-membros quanto a outros elementos atinentes à construção de uma constituição". ${ }^{99}$

Mas a pauta de ampliação dos limites horizontais da Comunidade não foi fixada formalmente. Não se alteraram os Tratados nem se discutiu, em nível supranacional, a necessidade de transformar o processo de aproximação econômica em algo quali-

99 The Constitution of Europe, cit., p. 24. Para investigações mais aprofundadas do mesmo autor, acerca do passado e do futuro da Corte, confira-se Journey to an Unknown Destination: A Retrospective and Prospective of the European Court of Justicein the Arena of Political Integration, cit., pp. 417-446. 
tativamente mais amplo e profundo. A questão surgiu no horizonte em face de controvérsias concretas, de disputas entre particulares. Ou seja, mais uma vez foi a Corte de Justiça quem enfrentou (e resolveu) o problema.

Em 1967, a Corte Constitucional da República Federal da Alemanha afirmou que a ordem jurídica comunitária não dispunha de fundamentos democráticos, eis que não previa a proteção de Direitos Humanos ${ }^{100}$. Por decorrência, era assegurado aos cidadãos alemães obter tutela em face dos poderes internos alemães, cuja ordem jurídica prevaleceria em face do Direito Comunitário no âmbito de Direitos Fundamentais. Diante desse "incentivo", a Corte de Justiça começou a imprimir a suas decisões uma forte conotação de tutela aos Direitos Humanos. Pode lembrar-se julgado relevante, conhecido como "Casagrande"101, que aplicou o princípio da não-discriminação a campos não econômicos. O litígio instaurou-se a propósito de lei alemã que assegurava bolsa de estudos para alunos que obtivessem determinado desempenho escolar. Um italiano atendeu a todos os requisitos mas foi-lhe negado o auxílio, porque reservado privativamente aos alemães (ou estrangeiros em situação de asilo). A Corte entendeu que vedação à discriminação ao trabalho devia ser interpretada amplamente, concluindo que os objetivos comunitários podiam ser comprometidos através de provisões discriminatória no âmbito de educação e treinamento. Já no caso $4 / 73$ (Nold v. Comission) ${ }^{102}$, a Corte firmou que os direitos fundamentais formam parte dos princípios gerais do Direito, cuja observância é assegurada pelo Direito Comunitário e cujo conteúdo é extraído das tradições comuns aos diferentes Estados-membros.

Em nenhum momento, porém, a Corte admitiu exame da compatibilidade do Direito interno de um Estado-membro em face dos princípios fundamentais atinentes aos Direitos Humanos. Somente se põe a questão dos Direitos Humanos quando relacionada a algum tema pertinente à ordem comunitária. Esse tipo de abordagem ficou claro no Caso 186/87 (Cowan v. Trésor Public) ${ }^{103}$. Um cidadão britânico foi assaltado em Paris, sofrendo sérias lesões físicas. Pretendeu indenização prevista na lei francesa, mas condicionada à nacionalidade francesa ou residência na França. A Corte reconheceu que a não-discriminação envolvia não apenas fornecimento mas também fruição de serviços. Considerou o interessado, um turista, como potencial fruidor de serviços, o que impedia tratamento discriminatório. $\mathrm{O}$ julgado permite apanhar o enfoque peculiar da Corte. Não se reconheceu a existência de Direito Fundamental, generalizável a todos os seres humanos (independentemente de sua nacionalidade). $O$ fundamento da extensão do direito não foi sua natureza intrínseca (Direito Fundamental), mas a prevalência do princípio da liberdade de circulação e da uniformidade de regime jurídico para os serviços. Ampliou-se a abrangência do princípio da não-discriminação através da fórmula de considerar um "turista" como um tomador de serviços, do que decorreu uma abordagem de natureza econômica.

100 Confira-se em MANCINI, A Constitution for Europe, cit., p. 609.

101 Caso 9/74, [1974] ECR 773-785.

102 [1974] ECR 491.

103 [1989] ECR 220-221. 
Seguindo essa orientação, a Corte tem destacado a prevalência dos princípios comunitários propriamente ditos. Em outras palavras, nunca se estabeleceu que a tutela a Direitos Humanos consistiria finalidade própria do Direito Comunitário, mas se abriu o projeto comunitário a dimensões não econômicas, desde que pertinentes aos fins comunitários ${ }^{104}$.

\section{XIII.3) A consagração da tutela aos Direitos Fundamentais em Amsterdā}

As inovações desenvolvidas através da jurisprudência foram incorporadas, finalmente, na versão dos Tratados aprovada em Amsterdã. Afirmou-se explicitamente o compromisso da UE com os Direitos fundamentais, mantida a fórmula desenvolvida pela jurisprudência da Corte. O TUE passou a dispor ser objetivo fundamental manter e desenvolver a União como um "espaço de liberdade, de segurança e de justiça" (art. 20). $\mathrm{O}$ art. $6^{2}$ afirma que "A União é fundada sobre os princípios da liberdade, da democracia, do respeito aos direitos do homem e das liberdades fundamentais, assim como do Estado de Direito, princípios que são comuns aos Estados membros". O art. $7^{\circ}$ prevê sancionamento contra Estados-membros que pratiquem violações aos princípios fundamentais do art. $6^{\circ}$. $O$ art. 49 condiciona $o$ ingresso de outros Estados europeus na UE à observância dos princípios do art. $6^{\circ}$. Isso tudo não autoriza questionamento a Direito nacional fundado exclusivamente na ofensa a princípios fundamentais sem vínculo com alguma manifestação de interesse comunitário. ${ }^{105} \mathrm{~A}$ Corte de Justiça aprecia temas pertinentes exclusivamente a Direitos Humanos apenas no âmbito da organização comunitária propriamente dita, em questões sem efeitos relativamente aos Estados-membros ${ }^{106}$.

É possível concluir, portanto, que a temática de Direitos Fundamentais apresenta relevância comunitária no âmbito da colisão de Direitos ou de princípios, quando então se aplicam as soluções desenvolvidas no âmbito dos Direitos nacionais, orientadas à realização conjunta e harmônica de princípios de diferente natureza.

104 Essa abordagem apresenta outra "vantagem", consistente em limitar a tutela a Direitos Fundamentais para o nacionais da UE. Se o fundamento das decisōes fosse a natureza de Direito Fundamental, então todas as pessoas teriam acesso ao tratamento não discriminatório.

105 Para esse fim, a solução é recorrer à Corte Européia de Direitos Humanos.

106 Como exemplo, pode referir-se ao Caso C-404/92 P (X v Comissão das Comunidades Européias), em que a Comissão pretendeu condicionar o recrutamento de servidores a exame para diagnóstico do vírus da AIDS. A Corte consignou que "Interpretar que provisóes relativas ao exame médico para fins de recrutamento de um membro do quadro temporário como impondo o dever de respeitar a recusa por uma pessoa relativamente apenas ao teste específico de diagnóstico da Aids mas permitindo a realizaçāo de quaisquer outros testes que possam simplesmente indicar a possivel presença do vírus da Aids prejudicaria a finalidade do direito de respeito à vida privada. A observância a esse direito demanda que a recusa da pessoa interessada seja respeitada completamente. Quando aquela pessoa expressamente recusou submeter-se a um teste de diagnóstico da Aids, aquele direito impede que a instituição interessada promova qualquer outro teste apto a determinar ou estabelecer a existência daquela doença" (ECR [1994] I-4738). 
O empreendimento desenvolvido pela Corte de Justiça teria pequena dimensão se não fosse acompanhado de produção normativa correspondente, de nível derivado. O Direito Comunitário não se resume às disposições dos Tratados, mas se materializa em enorme quantidade de normas produzidas pelo Conselho e pela Comissão. Supondo-se o Direito Comunitário como um sistema, sua estrutura está determinada através dos princípios fundamentais constantes dos Tratados e desenvolvidos pela Corte de Justiça (supremacia do Direito Comunitário, aplicabilidade direta, preempção). O repertório do sistema é constituído por algumas regras dos Tratados e pela imensa maioria de regras derivadas emitidas pelos órgãos comunitários.

\section{XIV.1) Fontes formais do Direito Comunitário}

O Direito Comunitário originário ou primário compreende os Tratados, assim como outros atos de natureza constitutiva (tal como o Ato Único Europeu de 1986, os protocolos e declarações anexas). ${ }^{107}$ A natureza originária deriva de uma produção direta da vontade comum dos Estados-membros.

O Direito derivado ou secundário é produzido pelas instituições comunitárias e seu elenco está no art. 249 do TCE, que arrola as seguintes espécies: a) regulamento; b) diretiva; c) decisão; d) recomendações e avisos ("avis" na versão francesa, "opinions" na inglesa). É problemática diferenciação teórica e homogênea entre as diferentes figuras. Pode dizer-se que regulamento é ato normativo de competência do Conselho, destinado a disciplinar diretamente relações jurídicas, com força vinculante não apenas para os Estados mas também para as demais categorias de sujeitos. $\hat{E}$ apto a produzir efeitos diretamente na órbita interna, produzindo uniformização do Direito europeu. Já a diretiva consiste em ato de competência da Comissão, destinado a vincular os Estados-membros e cumprir uma função de harmonização. Não se configura propriamente como fonte primária de direitos e obrigações, mas impõe aos diferentes Estados o dever de legislar para integrar em suas ordens jurídicas as regras e princípios contidos nas diretivas ${ }^{108}$. As decisões são dirigidas a um ou mais Estados-membros, com natureza concreta e objeto delimitado. As recomendaçōes e avisos têm função acessória, comparáveis a figuras de importância secundária no âmbito das concepções clássicas sobre fontes formais do Direito.

107 Ainda como dotados de condição de direito originário, aponta-se a decisão de 21 de abril de 1970, relativa a recursos orçamentários e o Tratado de Bruxelas de 1984, versando sobre a Groenlândia.

108 A transposição das diretivas para o Direito interno deverá fazer-se de acordo com as fontes consagradas em cada sistema. Mas deverá utilizar-se a via prevista para produção de normas obrigatórias, sendo vedada transposição através de simples “avisos ministeriais". Nesse sentido e dentre outros julgados, confira-se decisão no Caso C-360/95, [1997] ECR 7.337/7.350. 
Formalmente, não são fontes de Direito Comunitário nem a jurisprudência nem o costume. Mas é impossível apreender a natureza e extensão do Direito Comunitário sem conjugar as normas formalmente produzidas com a atuação jurisprudencial e os costumes vigentes no âmbito comunitário. Ou seja, a disputa acerca das fontes formais adquire contornos muito mais problemáticos no âmbito do sistema comunitário do que se passa ao interno das ordens jurídicas nacionais. $O$ processo de constitucionalização evidencia que a jurisprudência é fonte formal do Direito Comunitário, mesmo que tal possa ser negado pela própria Corte.

\section{XIV.2) Dualismo e unitarismo no âmbito do Direito Comunitário}

Como já afirmado, é problemático aplicar ao âmbito comunitário a classificação sobre os sistemas de internalização de normas de tratados e convenções internacionais. A distinção entre sistemas dualistas e unitários funda-se na necessidade ou não de atos formais para a incorporação no Direito interno das normas contidas em tratados. No caso das normas comunitárias, existem tanto características unitárias como dualistas. Assim, as normas do Direito Comunitário originário se integram automática e diretamente no Direito nacional. Aqui se aplica o princípio do efeito direito e imediato. Já as normas de Direito derivado podem ou não dispensar atos formais dos Estados-membros para sua integração nas ordens locais. Assim, os regulamentos produzem efeitos diretos, enquanto as diretivas dependem de incorporação através de fontes normativas nacionais.

É importante destacar que a natureza da UE é avessa à emissão de regras derivadas diretamente aplicáveis no âmbito interno dos Estados. De modo geral, não há competência para regulamentos, já que os órgãos da UE não são dotados de poder legiferante relativamente à ordem interna dos Estados-membros. A via precípua de funcionamento da UE é a diretiva. Nessa linha, o conteúdo da diretiva nunca poderia ser diretamente invocável no âmbito interno. No entanto, a jurisprudência da Corte de Justiça produziu evoluçōes significativas quanto a isso.

Em primeiro lugar, reconheceu-se que essa produção normativa de cunho derivado promovida pelos órgãos comunitários não se assemelha a avenças internacionais. ${ }^{109}$

Depois, estabeleceu-se que diretivas suficientemente claras e precisas poderiam ser invocadas diretamente por particulares contra o Estado que deixasse de adotar as providências adequadas à sua internalização. ${ }^{110} \mathrm{~A}$ doutrina costuma indicar essa

109 No julgamento da causa conhecida como "detergentes", a Corte estabeleceu que "[U]ma medida que tenha a configuração de decisão ou diretiva Comunitária, quando vista sob a perspectiva de seus objetivos e da estrutura constitucional em que foi produzida, não pode ser descrita como um 'acordo internacional'." (Caso 91/79, [1980] ECR 1.101).

110 Caso 152/84 (Marshall v. Southampton and South-West Hampshire Area Health Authority). Fixou-se que "Sempre que as provisöes de uma diretativa configurem-se, quanto ao tema que lhes concerne, como sendo incondicionais e suficientemente precisas, suas provisōes podem ser invocadas por um particular contra o Estado se esse Estado deixou de introduzir a diretiva no Direito 
situação de "efeito direto vertical". O entendimento da Corte fundou-se em que o Estado não poderia locupletar-se de sua própria desídia. A regra somente se aplicaria na relação entre particulares e Estado, não no âmbito de particulares entre si.

Isso não significa, no entanto, que as cortes nacionais aceitem sempre e satisfatoriamente essas concepções. Assim e recentemente, o Conselho de Estado francês "reafirmou a impossibilidade de um particular invocar as estipulações de uma diretiva como fundamento de um recurso dirigido contra um ato administrativo não regulamentar" 111 .

Por outro lado, a Corte já reconheceu que sua jurisprudência "não autoriza que uma provisão de uma diretiva que não foi implementada no Direito nacional no prazo limite fixado seja invocada por um particular contra outro particular a quem, em face do artigo 189 do Tratado EEC, a diretiva não foi dirigida". Ou seja, a diretiva não possuiria "efeito direto horizontal".

Mas tal não afasta, no entanto, o dever da corte local de interpretar o Direito nacional "à luz das palavras e dos propósitos da diretiva" 12 , inclusive para evitar resultados proscritos por ela. A isso se denomina de "efeito indireto" da diretiva ${ }^{113}$. Os fatos concretos de uma causa permitem aprender o caminho seguido pela Corte. Em determinada causa, pleiteava-se declaração de "nulidade" de uma sociedade, o que aparentemente poderia ser obtido em face do Direito espanhol mas era incompatível com a Diretiva 68/151/EEC. A solução adotada pela Corte foi assegurar os efeitos da "nulidade", mas sem produzir seu extrapolamento fora da relação entre as partes (enfim, uma modalidade de "desconsideração da pessoa jurídica"). No caso, era possível (?) interpretar o Direito local à luz da diretiva. O efeito indireto pode ser assemelhado a uma espécie de "interpretação conforme", largamente praticada no âmbito dos Estados nacionais. Existindo diferentes alternativas em face do Direito local, deve adotar-se aquela compatível com a diretiva. Em outra oportunidade, a Corte insistiu que a lei local teria de ser interpretada o máximo possível ("as far as possible") segundo o disposto na diretiva ${ }^{114}$. Em outras palavras, deve realizar-se a vontade das normas comunitárias mas mantendo a autoridade do Direito local. É inquestionável, no entanto, a existência de limites para o efeito indireto.

nacional até o término do período determinado ou se ele deixou de implementar corretamente a diretiva" ([1986] ECR 724). No entanto, a natureza vinculante da diretiva apenas existe em relação ao cada Estado-membro, do que se "segue que uma diretiva não pode ela própria impor obrigações a um particular e que uma provisão de uma diretiva não pode ser invocada para esse fim contra um particular" (idem, 725).

111 Conforme PAUL CASSIA, Le Juge Administgratif Français et la Validité des Actes Communautaires, em RTD eur 35(3), juill.-sept. 1999, p. 409.

112 Caso C-106/89, Marleasing SA v. La Comercial Internacional de Alimentación SA, [1990] ECR I-4161).

113 Sobre o tema, consulte-se GERRIT BETLEM, The Principle of Indirect Effect of Community Law, European Review of Private Law, 3:1-19, 1995, e ROBERTO MASTROIANNI, On the Distinction between Vertical and Horizontal Direct Effects of Community Directives: What Role for the Principle of Equality?, European Public Law, vol. 5, issue 3, September 1999, pp. 417-435. 114 Caso C-91/92, Faccini Dori v. Recreb, [1994] ECR I-3347/3359. 
Haverá casos em que o Direito local não comportará solução conforme o conteúdo das normas comunitárias. O tema foi objeto de apreciação no caso Arcaro, em que se questionava o princípio da legalidade penal. Em síntese, um particular cometeu atos que, se uma certa diretiva tivesse sido devidamente internalizada, caracterizariam crime. A CJCE fixou que "o dever da corte nacional de considerar o conteúdo de uma diretiva na interpretação das regras pertinentes de seu Direito nacional atinge a um limite quando semelhante interpretação conduzir à imposição a um particular de uma obrigação prevista em uma diretiva que não foi transposta ou, mais especialmente, quando isso tiver o efeito de determinar ou agravar, com base na diretiva e na ausência de uma lei produzida para sua implementação, a responsabilidade penal de pessoas que agem em contravenção às previsões daquela diretiva"115.

\section{XIV.3) A doutrina "Francovich"}

A ausência de transposição do Direito Comunitário pode inviabilizar o exercício de direitos ou a fruição de garantias pelos particulares. Há limites para os efeitos indiretos. Sendo impossível a "interpretação corretiva", a única alternativa para o particular prejudicado pela ausência de tempestiva e adequada internalização da diretiva seria pleitear indenização por perdas e danos contra o Estado. Nos Casos C-6/90 e C-9/90, conhecidos como "Francovich", a Corte estabeleceu que "[A] completa eficácia das regras comunitárias seria lesada e a proteção dos direitos por elas garantidos seria enfraquecida se os particulares não pudessem obter reparação quando seus direitos fossem infringidos em virtude da violação da lei comunitária de responsabilidade de um Estado-membro. Essa possibilidade de reparação por parte do Estado-membro é particularmente indispensável quando a eficácia integral das regras comunitárias depender de prévia atuação por parte do Estado e quando, conseqüentemente, na ausência de tal atuação, os particulares não puderem invocar frente às cortes nacionais os direitos a eles conferidos pela lei comunitária. Daí deriva que o princípio pelo qual o Estado deve responder por perdas e danos sofridos pelos particulares por violações à lei comunitária pelas quais o Estado possa ser considerado responsável é inerente à sistemática do Tratado"116.

A doutrina "Francovich" tem produzido inúmeros desdobramentos, dando origem a novas vertentes para a responsabilidade civil do Estado. No entanto, o tema não mereceu maior aprofundamento teórico ou prático, até mesmo pela dificuldade inerente à teoria da responsabilidade por ato omissivo ${ }^{117}$.

115 Caso C-168/95, [1996]ECR I-4706.

116 [1991] ECR I-5.358.

117 Acerca da questão, podem conferir-se os ensaios de GUIDO ALPA (Problemi attuali in tema di responsabilità della Pubblica Amminstratizione: lesione di interessi legittimi ed illecito comunitario) e de VICENZO ROPPO (La responsabilità civile dello Stato per violazione del diritto 
A comunitarização afeta diferentes ângulos da vida social dos Estados-membros. A riqueza e multiplicidade de aspectos do fenômeno impossibilitam abordagen globalizadora sobre isso. Mas há alguns tópicos que merecem referência, ainda que algo simplista.

\section{XV.1) A amplitude da comunitarização e os diferentes ramos do Direito}

No percurso de implantação de uma Europa unificada, o Direito Comunitário vai atingindo diferentes espécies de relações jurídicas. Como decorrência, pode aludir-se ao surgimento de um Direito Civil Comunitário, de um Direito Comercial Comunitário, de um Direito Penal Comunitário, de um Direito Administrativo Comunitário e assim por diante. Cada ramo do Direito comporta uma vertente comunitária e uma nacional. Resta como competência de cada Estado nacional disciplinar as relações jurídicas que não tenham pertinência a essa órbita comunitária. Assim, por exemplo, o conceito de "pessoa jurídica" passou a ser significativamente influenciado pelo Direito Comunitário, na medida em que a atuação empresarial adquire contornos supranacionais. Daí a disciplina das sociedades anônimas européias. O Direito Comercial é aquele mais fortemente absorvido pelo âmbito comunitário, por motivos mais do que evidentes: seu objeto (em termos amplos) abrange primariamente a regulação das atividades empresariais, o que coincide com o campo primordial do Direito Comunitário. No entanto, mesmos ramos do Direito relacionados a peculiaridades nacionais foram fortemente influenciados pela comunitarização. É o caso do Direito Administrativo. O Direito Comunitário não interfere sobre a organização política de cada Estado nem com a disciplina da atividade administrativa, questões estritamente internas e locais. Mas não é compatível com o Direito Comunitário invocar a natureza "política" da atividade administrativa para impedir a prevalência dos princípios fundamentais da UE. A decorrência é a rigorosa rejeição a privilégios ou monopólios, caracterizadamente relacionados ao regime dos serviços públicos, e a submissão da atividade contratual administrativa a princípios padronizados. Esses segmentos do Direito Administrativo perderam conotação nacionalista e se integraram parcialmente ao regime jurídico da UE.

Em suma, é inviável compreender um ramo específico do Direito, no âmbito da estruturação européia, sem conhecer os vínculos com a UE. Os institutos peculiares ao diferentes ramos são submetidos aos efeitos da comunitarização. A experiência do passado e as características do processo comunitário permitem inferir que essa tendência se manterá no futuro.

comunitario [con una transgressione nel campo dell'illecito 'constituzionale' del legislatore]), em Contratto e impresa / Europa, Cedam 1999, 1, pp. 83-100 e 101-123). 
A comunitarização se manifesta como um processo de homogenização dos direitos nacionais, tal como exposto acima. A dialética da europeização se traduz na supressão das peculiaridades mais acentuadas que cada uma das ordens jurídicas locais vivenciava. O Direito Comunitário acaba traduzindo como uma espécie de "mínimo comum", incompatível com a manutenção do que se poderia qualificar como especificidades idiossincráticas nacionais. Em princípio, essa dinâmica atinge apenas as áreas sujeitas ao campo do Direito Comunitário, mas será difícil a convivência de dois sub-sistemas absolutamente autônomos, sujeitos a princípios e regras distintas. Pode estimar-se que o Direito Comunitário tenderá a prevalecer, com a difusão de seus princípios para o âmbito dos regimes locais. É improvável que os Estados-membros mantenham, a médio prazo, institutos jurídicos de configuração distinta daqueles impostos pelo Direito europeu. Tal se imporá inclusive em virtude do princípio da isonomia. Um exemplo permite apreender a problemática. No Direito italiano, era reconhecida competência discricionária na promoção de contratos administrativos, inadmitindo-se direito de impugnação pelos particulares. O Direito Comunitário disciplinou o assunto, prevendo licitação para contratações de valor superior a 200.000 euros e impondo observância ao devido processo legal. A legislação italiana foi alterada, prevendo inclusive direito de recurso contra os atos de seleção de contratantes. Mas a regra destina-se, em princípio, ao círculo das contratações sujeitas aos efeitos das diretivas comunitárias. Será cabível restringir impugnação apenas atos pertinentes a contratos com valor superior a certo limite? A doutrina italiana já começou a invocar o princípio da isonomia como fundamento para generalização do direito de agir, seja na via administrativa, seja no âmbito jurisdicional.

O processo de comunitarização envolve supressão de diferenças e ampliação de semelhanças. A natureza reducionista se evidencia como tendência a eliminar diferenças inconciliáveis, suprimir peculiaridades impossíveis de difusão, com o desaparecimento de características inúteis sob o ponto de vista dos fins a que se orienta o processo (ainda que eventualmente compreensíveis em face de origens históricas). Isso importa sacrifício de experiências locais, cuja manutenção poderá fazer-se apenas sob uma dimensão simbólica e irrelevante.

A natureza ampliativa exterioriza-se como prevalência de vocações comuns e apropriação de experiências externas que se afiguram como úteis, geralmente norteados por critérios econômicos. Os princípios jurídicos tradicionais de um país são substituídos por padrões adotados em outros ambientes. Os novos institutos são impostos não necessariamente porque mais eficientes ou adequados, mas também por serem mais conhecidos e difundidos. O critério da comodidade do operador econômico pode impor-se e ser decisivo como causa da eliminação de determinado instituto.

Como regra, a supressão é sempre compensada por um acréscimo, o que pode ser interpretado como forma de mudança ou substituição. Excetuadas hipóteses excepcionais, comunitarização não significa simples eliminação de institutos nacionais, mas sim sua substituição por institutos de configuração supranacional. A 
homogenização se caracteriza como resultado da imposição de institutos uniformes e idênticos. É inquestionável, no entanto, a natureza dialética do processo, porque sempre se produz inovação qualitativa na configuração das novas soluções. Os novos institutos como que se impregnam de algumas características dos anteriores. Enfim e como acima afirmado, a comunitarização não corresponde à difusão para o mundo externo de um modelo específico de um dos países integrantes da UE. Mais do que "generalização", o processo pode ser qualificado como "sintetização".

Vários exemplos podem ser fornecidos a propósito. Talvez a mais intensa manifestação dessa natureza da comunitarização resida na aproximação dos modelos jurídicos anglo-saxão e continental. Sempre se puseram diferenças essenciais entre os dois sistemas. Por exemplo, enquanto o continental envolvia a prevalência da função legislativa, o anglo-saxão se fundava no costume e na jurisprudência ${ }^{118}$. A comunitarização alterou o panorama. Por um lado, ampliou-se a relevância da "lei" como fonte normativa no âmbito anglo-saxão, cujos tribunais passaram a reportar-se aos Tratados como uma espécie de constituição escrita (outra inovação de grande dimensão). Mas a influência da tradição anglo-saxã pode ter influenciado a função desempenhada pela jurisprudência da Corte na constitucionalização dos Tratados.

Para concluir, é importante destacar a preocupação que tem surgido no seio da UE acerca da defesa do pluralismo, eufemismo utilizado para indicar as peculiaridades nacionais ${ }^{119}$. Não se trata, em sentido próprio, de proteger posições minoritárias ao interno de cada Estado, mas de assegurar a sobrevivência das peculiaridades locais. Sob a expressão pluralismo europeu, albergam-se os problemas de diferenças profundas entre os países-membros. O tema é fascinante, mas escapa aos limites deste trabalho.

\section{XV.3) Superação da dualidade de jurisdições?}

Outra questão interessante reside em que a CJCE concentra competência para conhecer tanto questões de "Direito Administrativo" quanto relativas a matérias comuns. Tem apreciado incidentes envolvendo processos pertinentes ao contencioso administrativo como à justiça comum. Sob esse ângulo, a Corte funciona como uma espécie de "órgão de cúpula" das jurisdições nacionais, com efeitos uniformizadores e harmonizantes. Isso pode significar a aproximação dos princípios pertinentes a ambas as estruturas jurisdicionais. É pouco provável que tradições tão fortemente arraigadas nas ordens locais, tal como a dualidade de jurisdições, sejam eliminadas. Por exemplo, não é plausível imaginar que a França viria a abdicar da existência de

118 Essa é uma evidente simplificação, até porque a relevância do direito legislado foi-se ampliando ao longo no tempo, no âmbito anglo-saxão.

119 RICHARD MÜNCH afirma que "(a)cima de tudo, o processo de estandardização traz à consciência pública a diferença entre as regiōes e enfatiza-a com vista a salvaguardar identidades regionais" (Between nation-State, Regionalism and World Society, Journal of Common market Studies, vol. 34, $n^{\circ} 3$, September 1996, p. 399). 
seu contencioso administrativo. No entanto, é inquestionável que a competência comum da CJCE produzirá efeitos atenuantes da dualidade de jurisdições.

Sob esse ângulo, pode aludir-se a homogenização interna aos diferentes ordenamentos nacionais. As diferenças propiciadas pela dualidade de jurisdições serão reduzidas, com perspectivas de forte identificação dos critérios e princípios decisórios.

\section{$\mathrm{XVI}-A$ natureza da $U E$}

Todas as questões acima desenvolvidas se relacionam, em maior ou menor intensidade, com a definição da natureza jurídica da UE. É possível discutir se a UE apresenta-se como um sujeito de direito internacional público, com personalidade própria, distinta da dos seus membros. Essa indagação é relativamente simples de ser resolvida. Mas é cabível ir mais avante, questionando se essa entidade pode ser configurada como um Estado. O tema tem despertado a atenção da doutrina e centralizado atenções não apenas no âmbito jurídico, mas também político. A quantidade de estudos é enorme, sendo inviável mesmo enumerar as diferentes propostas. Pode dizer-se que a maior parte das concepções reconhece que a "União consiste numa mistura única de propriedades federais e confederativas" 120 Essa orientação se orienta pela idéia da natureza sui generis da UE, fundada em propostas desvinculadas das concepçōes clássicas.

Sobre o tema, é interessante sistematização das diversas abordagens, proposta por JAMES A. CAPORASO ${ }^{121}$, distinguindo três enfoques diferentes. Poderia aludir-se a uma visão tradicional ${ }^{122}$ (fundada nas concepções formalizadas no Tratado de Westfália), uma concepção reguladora e uma postura pós-moderna. Para fins mesmo didáticos, vale inverter a ordem da exposição do autor, o que permite melhor aproveitamento de seu potencial.

\section{XVI.1) A concepção de um Estado regulador}

Segundo essa visão, o conceito de Estado não pode ser aplicado apenas aos "Estados completos", dotados de poderes em todos os segmentos de disciplina da conduta intersubjetiva. Deve reconhecer-se a natureza de Estado a entidades dotadas

120 DIMITRIS N. CHRYSSOCHOOU, New Challenges to the Study of European Integration: Implications for Theory Building, Journal of Common Market Studies, vol. 35, $\mathrm{n}^{\mathbf{2}} 4$, December 1997, p. 523.

121 The European Union and forms of State: Westphalian, Regulatory or Post-Modern?, Journal of Common Market Studies, vol. 34, $\mathrm{n}^{\circ}$ 1, March 1996, pp. 29-52.

122 A expressão "tradicional" tem de ser compreendida em termos. Alude à experiência dos últimos duzentos anos da organizaçāo política estatal nas sociedades ocidentais. Sob um certo ângulo, somente é possível identificar o "clássico" em oposição ao inovador - no caso, a inovação é trazida pelo modelo da UE. 
do poder de disciplinar um segmento de relações jurídicas. Haveria, portanto, diferentes espécies de Estados. Além daqueles de modelo clássico (fundados no instituto da "soberania" em sentido próprio), também existiria a UE, cujo natureza é distinta do Estado-Nação de perfil clássico. A finalidade da existência da UE é restrita à a regulação de certas atividades.

Adotar essa concepção equivale a afirmar ser a UEA uma entidade meramente regulatória, cujos poderes vinculam os Estados-membros, mas apenas nos campos objeto dessa regulação. Não incumbe (nem nunca incumbirá) à UE executar as regras que elabora. Trata-se, por assim dizer, de um Estado unidimensional, por assim dizer, eis que não envolve perspectivas sociais e traduz compromissos políticos muito restritos. Não assume deveres de prover as necessidades dos cidadãos, nem está diretamente comprometido com a promoção da justiça social ou de outros valores. Enfim, é um Estado instrumental.

Essa concepção exclui perspectivas de mutação futura substancial da UE, tanto quanto nega a incompletude do modelo atual. Ainda reconhecendo que se trata de um projeto em vias de desenvolvimento, a UE não seria vocacionada a assemelhar-se a um Estado de perfil clássico. As modificações trazidas pela evolução se relacionariam com a amplitude da competência regulatória da UE, que poderia expandir-se ou contrair-se. No entanto, a UE nunca experimentaria modificações qualitativas, nem teria a perspectiva de adquirir soberania na acepção tradicional. Sua soberania consistiria em seu poder de regulamentar certo âmbito de atividades, com força impositiva inquestionável e vinculante. Para essa teoria, a UE seria Estado dotado de uma soberania restrita e peculiar, seletiva.

\section{XVI.2) A concepção de um Estado pós-moderno}

A concepção pós-moderna apresenta alguma relação com a idéia de Estado regulador. Propõe a revisão dos enfoques tradicionais sobre organização e concentração do poder. A revolução tecnológica produziu novos instrumentos de dominação. Sob a perspectiva dessa nova ordem, soberania é o poder de excluir (povo, capital, idéias etc.). O Estado pós-moderno apresenta-se como uma entidade abstrata, não no sentido de ausência de exercício de poderes políticos, mas pela superação dos instrumentos materiais tradicionais. Não se trata mais de forma de manifestação da "soberania popular", eis que o Estado pós-moderno não contempla espaços públicos de manifestação de idéias contrapostas ou de competição entre diferentes propostas políticas. O poder de determinar os processos e atividades sociais, econômicos, jurídicos, culturais e políticos é o núcleo dessa nova manifestação de Estado. Sob um certo ângulo, o Estado pós-moderno é fenômeno destituído de força, muito difuso, eis que não se exterioriza em instituições concretas e palpáveis. Mas isso não deve induzir que se trate de um Estado fraco, eis que dispõem de instrumentos para controlar a vida individual e coletiva, determinar os objetivos a atingir e neutralizar seus opositores. 
A UE se configuraria como uma forma de Estado pós-moderno pela titularidade de grandes fatias de poder, exercitáveis em face dos Estados-membros e das populações nacionais ${ }^{123}$.

XVI.3) Estudos “pós-ontológicos"?

Segundo CAPORASSO, os estudos sobre a UE abandoram a preocupação de discutir sua natureza específica. Passou-se a uma abordagem "pós-ontológica", em que as controvérsias envolvem temas concretos e determinados, sem a pretensão de determinar a consistência ôntica da UE. De acordo com essa proposta, não teria muito sentido indagar se a UE é um Estado ou se detém soberania. $O$ fundamental seria examinar os poderes de que é titular, sem formulações teóricas abrangentes e abstratas. Seguindo essa proposta, os estudiosos deveriam dedicar-se ao exame dos diferentes aspectos da UE, deixando de lado as disputas acerca da sua "natureza jurídica".

Concepção dessa ordem não se afigura procedente. Em primeiro lugar, negar interesse científico no exame da natureza jurídica da UE é cientificamente indefensável porque continuam existindo Estados modelados segundo a concepção clássica. Se a noção clássica de Estado não mais correspondesse a qualquer fenômeno concreto, até se poderiam considerar novos conceitos ou configurações para o Estado. Caracterizar a UE como modalidade diversa de Estado não elimina a necessidade (teórica, mas não apenas) de enfrentar questões relacionadas com temas clássicos.

Em segundo lugar, as concepções "pós-ontológicas" importam tomada de posição subjacente. Afirmar que a UE é "apenas" um Estado Regulador ou "pós-moderno" equivale a asseverar que não se trata de Estado na acepção clássica. Como os Estados-membros são Estados numa acepção clássica, resulta evidente a definição (ainda que implícita) da natureza jurídica da UE. Um Estado exclusivamente regulador ou "pós-moderno" pode ser qualquer coisa, mas não Estado na acepção clássica. Porém, quem afirma que a UE não é um Estado na acepção clássica tem de justificar sua afirmativa. Não é suficiente afirmar ser a UE um Estado regulador — asserção que até pode ser procedente. É imperioso justificar porque seria "apenas" um ente regulador e não um Estado no sentido clássico. Em última análise, essas teorias são defeituosas não tanto pelo que afirmam, mas pelo que negam. Mais ainda, o defeito não reside propriamente na negativa. Até pode ser verdade que a UE não é um Estado em sentido clássico. O problema reside na recusa em examinar de modo direto aquilo que descaracteriza a UE como Estado em sentido clássico.

123 CHEVALIER observa que " $O$ direito europeu constitui-se sem nenhuma dúvida, pelo fato da ausência de suporte de um 'Estado', em um lugar privilegiado de emergência, dir-se-ia um 'laboratório de experimentação', das novas figuras da pós-modernidade jurídica" (Vers un Droit Post-Moderne? , cit., p. 672). 
Em terceiro lugar, essas propostas apresentam o efeito negativo de legitimação de carências políticas do modelo desenvolvido concretamente. Adotar os conceitos de Estado regulador ou de Estado pós-moderno torna impertinentes temas como "soberania popular", "legitimidade", "democracia". Certamente, essa não é uma perspectiva a compartilhar. Em suma, é imprescindível examinar a configuração da UE em face das concep̧̧ões clássicas.

\section{XVI.4) A concep̧̧ão tradicional de "Estado" e suas implicações}

A visão tradicional de Estado, na esteira do pensamento weberiano, refere-se a uma entidade titular do monopólio da violência, aparelhada através de organização administrativa permanente para arrecadar tributos e exercer a administração e estruturada por via de instituições e servidores para desenvolver atividades políticas. $O$ conceito fundamental é o de soberania, entendida como o reconhecimento da autoridade exclusiva e privativa para exercício de decisões respaldadas pela coerção no âmbito de um certo território. Até há algumas décadas, esse tópico era identificado como o núcleo do conceito de Estado, envolvendo a ausência de subordinação da vontade do ente político a alguma outra autoridade externa. A soberania consistia no poder de autodeterminação no plano externo e na faculdade de regulação na dimensão interna. $O$ conceito de soberania se identificava com o de supremacia jurídica e independência política.

Buscando os critérios tradicionais de identificação de um Estado, poderia fazer-se um sumário nos seguintes termos, acerca da situação da UE:

a) soberania

É evidente que a UE não é titular de soberania, considerada a expressão na acepção clássica. Não dispõe de aparatos organizacionais estruturados, aos quais se atribuam competências inerentes à soberania. Depende das estruturas de servidores existentes no âmbito de cada Estado-membro. Seria até desnecessário assinalar que a UE não é titular de um exército, nem de uma polícia, nem de servidores titulares de poder de impor-se em face de cidadãos. Não é dotada de órgãos de exercício de poder fático em relação a terceiros e nem lhe é viável impor fisicamente suas decisões. Não há um "território" comunitário propriamente dito, sobre o qual a Comunidade exercitasse poder autônomo e independente daquele titularizado pelos Estados-membros.

O art. 291 do TCE determina que a Comunidade goza, no território dos Estados-membros, de privilégios e imunidades necessários à realização de suas missões. Sob esse ângulo, a UE está mais próxima de uma organização internacional do que de um Estado soberano.

Por outro lado, a UE é dotada de poder para determinar aos órgãos locais as condutas a adotar, inclusive no tocante ao desfazimento de atos indevidos. Os órgãos comunitários dispõem de competência mandamental, com capacidade para imposição 
de sanções aos Estados em situação de infringência. ${ }^{124}$ Por outro lado, existe uma "cidadania comunitária", o que assegura a incidência de um regime jurídico próprio e igualitário, sem que isso importe reconhecer ao conjunto de cidadãos a soberania última da UE. É uma cidadania peculiar, portanto, eis que não envolve a plenitude dos direitos políticos.

\section{b) a soberania popular e o déficit democrático}

O problema da soberania não pode ser examinado sob uma dimensão exclusivamente formalista e estática. Pode qualificar-se como tal a concepção que visualiza a soberania como poder institucionalizado de decidir, nos planos externos e internos, em última instância e sem sujeição a constrangimentos derivados da vontade de outros Estados. Essa dimensão da soberania é acessória e secundária. A soberania como supremacia da vontade de uma organização política é decorrência da institucionalização da soberania popular. É a autonomia do povo que permite reconhecer uma certa organização política como Estado. Não é possível existir Estado sem um povo soberano, cujo reflexo se põe na existência de organizações políticas que vocalizam essa autonomia. A organização sócio-política do povo como conjunto autônomo é que configura o pressuposto da soberania, o que representa, sob certo ângulo, acolher definições tradicionais no sentido de que o Estado é a Nação politicamente organizada.

Ora, aí reside a grande peculiaridade da UE. Até se pode reconhecer algum tipo de identidade européia, mas certamente não existe qualquer vínculo entre a UE e o "povo europeu". A UE não se estrutura como manifestação política do povo europeu, mas porque se trata de entidade tecnocrática, alheia a formas de participação do povo. Esse tema vem sendo continuamente retomado pela doutrina ${ }^{125}$. Basta examinar a estruturação dos órgãos institucionais comunitários para confirmar a ausência de representatividade popular. O Parlamento europeu tem funções relativamente secundárias e seus membros, como já apontado, representam o povo de cada Estado-membro e não o povo europeu ${ }^{126}$. A Comissão é uma estrutura claramente tecnocrática, enquanto o Conselho retrata orientações políticas dos diferentes Executivos. Destaque-se que essa concepção não foi produto da casualidade. O modelo teórico da Comunidade Européia excluía, intencionalmente, a participação democrática ${ }^{127}$.

124 As sanções podem ser a suspensão dos direitos comunitários (TUE, art. $7^{2}$; TCE, art. 309) como também a condenação ao pagamento de valores determinados pela Corte de Justiça (TCE, art. 228 e seus diversos parágrafos).

125 Sobre isso e com aprofundamento incomparável, confira-se WEILER, The Reformation of European Constitucionalism, cit., p. 115.

126 Aliás, nāo existem partidos políticos europeus.

127 FEATHERSTONE, Jean Monnet and the "Democratic Deficit" in the EU, Journal of Common Market Studies, vol. 32, $\mathrm{n}^{2}$ 2, June 1994, pp.149-170. O autor cita trecho pretensamente atribuído a Monnet, em que ele teria afirmado que "IEu nunca acreditei que um belo dia a Europa poderia ser criada através de alguma grande mutaçāo política, e eu pensei ser errado consultar os povos da Europa acerca da estrutura da Comunidade, acerca do que eles não tinham experiência prática" (p. 159). Aliás, o texto reporta-se a uma frase de SPINELLI, no sentido de que "Monnet teve o 
Ainda com algum exagero. pode dizer-se que. se fosse um Estado, a UE seria um "Estado sem povo". Com mais cautela. deve dizer-se que reconhecer a natureza de Estado à UE depende de ou negar a necessidade de "povo" para existência de Estado ou sustentar que a UE se vincula indiretamente ao "povo" de cada Estadomembro. Ambas as alternativas são improcedentes, ainda que a segunda seja mais defensável.

Nesse contexto, é paradoxal a supremacia do Direito Comunitário face dos Direitos nacionais e e sua aptidão a produzir efeitos diretos no âmbito de cada Estado-membro. Surge indagação básica, acerca da possibilidade de existência de um Direito de nível hierárquico superior que não seja manifestação de uma soberania popular.

Observe-se que o Tratado de Amsterdã acolheu como fundamentais os princípios democráticos, cominando sanções contra Estados-membros que os violassem e subordinando o ingresso de novos Estados na União ao estrito respeito a eles. Pode dizer-se que os princípios democráticos têm de ser respeitados no âmbito de cada Estado-membro mas não são cogitáveis na dimensão comunitária. Esse é um caso em que o todo é menos do que a soma das partes.

\section{c) a questão da competência-competência}

Rigorosamente, a competência da UE é-lhe atribuida pelos Estados-membros. A UE não pode assumir os poderes que bem entender. No entanto, é um órgão de dimensão comunitária quem titulariza o poder de determinar quais são as competências dos Estados-membros e da União. A Corte de Justiça é aquele órgão que exerce a competência para proferir, com efeito de coisa julgada, a decisão final sobre a partilha de competências. Essa perspectiva tem motivado cortes nacionais a afirmarem como sua a competência para dizer a palavra final, tal como se verá adiante.

\section{d) personalidade de direito internacional público}

A UE é dotada de personalidade jurídica autônoma, inconfundível com aquela dos Estados-membros. Existem órgãos comunitários, que produzem atos imputáveis direta e exclusivamente à própria UE. Ela é titular de patrimônio próprio. Possui servidores que estão vinculadas a ela direta e exclusivamente. Dispõe do poder de agir no concerto das Nações, ainda que dita atuação dependa de observância de requisitos procedimentais rigorosos.

\section{e) capacidade para firmar tratados}

A UE parece ter recebido poderes para pactuar tratados, tal como se vê da regra geral dos art. 300 e 310 (TCE), ainda que se tenha omitido a expressão "tratados". Mas as competências são delimitadas a assuntos específicos e determinados e, na maior parte dos casos, a vinculatividade dos acordos internacionais depende da concordância do Estado-membro.

grande mérito de haver construído a Europa e a grande responsabilidade de havê-la construído erradamente" (id.. p. 150). 


\section{f) capacidade impositiva (autonomia econômico-financeira)}

A UE não é dotada de capacidade impositiva. Não pode exigir tributos dos cidadãos da UE. Sua manutenção faz-se através de contribuições desembolsadas pelos Estados-membros, mas segundo um orçamento aprovado anualmente pelos próprios órgãos comunitários (em que se destaca uma competência relevante para o Parlamento). Ou seja, não são os Estados-membros que fixam, espontaneamente, a dimensão de sua colaboração. Nem há perspectiva de recusa pelo Estado-membro de arcar com a parte que lhe cabe no custeio das despesas comunitárias. Enfim, embora não disponha de competência para impor tributos, a UE é titular do poder autônomo para fixar o valor com que os Estados deverão para ela contribuir.

\section{g) supremacia relativa do Direito Comunitário:}

O tema já foi acima exposto, mas não integralmente. Como visto, o Direito Comunitário superpõe-se ao Direito Nacional, no âmbito das competências comunitárias, produzindo efeitos diretos e indiretos. No entanto, é problemático afirmar que as regras comunitárias seriam hierarquicamente superiores à constituição dos Estados-membros. É bem verdade que a Corte Européia chegou a afirmar que "a validade de uma medida comunitária ou seus efeitos dentro de um Estado-membro não pode ser afetados por alegações de que ela contraria quer direitos fundamentais tal como formulados pel constituição daquela Estado como os princípios da estrutura constitucional nacional" ${ }^{128}$. Mas nenhum dos Estados-membros encamparia tal posição, inclusive por impedimentos lógicos. A adesão do Estado à ordem comunitária depende de autorização constitucional. Assim e por exemplo, a França teve de promover, em virtude de manifestação do Conselho Constitucional, modificação de sua Constituição para viabilizar a ratificação dos Tratados de Amsterdã ${ }^{129}$. Se a ordem comunitária fosse superior (hierarquicamente) às regras constitucionais nacionais, não seria sequer necessário emendar a constituição - não, ao menos, como " pressuposto" de adesão aos Tratados.

Mas o tema foi objeto de inúmeras manifestações explícitas por parte dos Estados-membros. Assim, a Corte Constitucional alemã recusou a possibilidade de transferência de poderes fundamentais a organizações internacionais, interpretação compartilhada por inúmeros outros Estados-membros. ${ }^{130}$ Por igual, a Corte Constitucional italiana afirmou que a Constituição italiana (e não a Corte Européia de Justiça) governava a relação entre a lei comunitária e o Direito italiano ${ }^{131}$. Também foi essa a posição do Conselho de Estado francês, no caso "Sarran", fixando que

128 Caso 11/70 (Internationale Handelsgessellschaft), [1970] ECR 1125-1136.

129 Sobre o tema, FLORENCE CHALTIEL, Droit Constitutionnel et Droit Communautaire, RTD eur., 35(3), juill.-sept. 1999, pp. 397-408.

130 Nesse sentido, BRUNO DE WITTE, Community Law and national Constitutional Values, em Legal Issues of European Integration, 1991, pp. 4/5.

131 Conforme ALEC STONE SWEET, Constitutional Dialogues in the European Community, em The Eurpean Court and National Courts - Doctrine and Jurisprudence, Oxford, Hart Publishing, 1998 , p. 314. 
os tratados internacionais não prevalecem sobre as regras constitucionais francesas. ${ }^{132}$ Segundo exposto por DE WITTE, "de todos os Estados-membros, somente a Holanda tem uma provisão constitucional (art. 120) que expressamente proíbe as cortes nacionais de revisar a constitucionalidade das provisões do Tratado" ${ }^{133}$. Portanto e excluído o caso da Holanda, todos os demais Estados podem judicar da constitucionalidade das regras do Direito Comunitário ${ }^{134}$.

A ausência de controversas mais intensas nessa área pode ter derivado da própria complexidade dos sistemas de controle de constitucionalidade adotados nos diferentes países. É possível que as restrições dos sistemas nacionais ao controle de constitucionalidade tenham acarretado efeito secundário, favorável à prevalência do Direito Comunitário. $O$ ponto fundamental reside em que as magistraturas nacionais têm o dever de não aplicar o direito nacional incompativel com o Direito Comunitário, mas não dispõem de alguma faculdade de controle do próprio Direito Comunitário. A Corte de Justiça nega às jurisdições nacionais o poder de fiscalização da regularidade das normas comunitárias ${ }^{135}$. Por outro lado e como regra, os sistemas nacionais negam ao magistrado o poder de rejeitar validade a uma norma sob fundamento de inconstitucionalidade. Esse controle costuma ser concentrado em órgãos específicos. Logo, é problemática a situação do magistrado nacional diante do conflito entre norma comunitária e a Constituição de seu Estado. Não dispõe de alternativa, a não ser aplicar a norma comunitária, pois assim se lhe impõe tanto pelo sistema comunitário como pelo Direito local. A não aplicação da norma comunitária dependerá da manifestação da Corte Constitucional, o que demanda longa demora e procedimentos complexos.

Portanto, a única solução para os Estados-membros defenderem os princípios fundamentais consagrados em suas Constituições residira em generalizar o poder de fiscalização da constitucionalidade, adotando sistema de controle difuso.

Para concluir, pode afirmar-se, ainda que chocante para uma visão tradicional, que a ordem comunitária prevalece sobre o Direito constitucional dos Estados-membros até certo ponto. O núcleo essencial das construções constitucionais (aquilo que, em face do Direito brasileiro, seria qualificado como "cláusulas pétreas") não pode ser suprimido pelo Direito Comunitário. Mas não é impossível que o Direito Comunitário discipline a extensão de direitos e garantias ou disponha acerca de matérias contidas nas diferentes constituições nacionais. Haverá limites variáveis em função da identidade e da soberania nacionais. A prevalência de uma ou outra ordem jurídica dependerá da relação política existente entre as diferentes instituições, em determinado momento.

132 FLORENCE CHALTIEL, Droit Constitutionnel et Droit Communautaire, cit., p. 397 e ss. 133 Ob. cit., p. 6.

$134 \mathrm{O}$ que não significa afirmar a impossibilidade de questōes constitucionais se colocarem no âmbito da Holanda. Apenas, a configuraçāo far-se-á segundo uma sistemática peculiar.

135 Ademias, a Corte se recusaria a declarar inválida norma comunitária sob fundamento de ofensa a Constituição de Estado-membro. 


\section{h) Sintese}

O exame da natureza da UE segundo concepções tradicionais de Estado comporta duas propostas diversas.

Uma, que poderia dizer-se "tradicional clássica", concebe a UE segundo os paradigmas dos séculos XVIII e XIX. Pretende que a UE destina-se a ser um corpo político comparável aos Estados nacionais desenvolvidos nos últimos duzentos anos. Segundo essa concepção, a UE estaria a trilhar o mesmo percurso já percorrido pelos Estados nacionais. Por isso, sua situação atual corresponderia a um estágio intermediário, destinado a completar-se segundo forma federativa ou confederativa. Essa abordagem conduz à análise dos institutos comunitários sob perspectiva de "modelo inacabado", sempre cogitando da complementação quando atingida etapa final, o que poderá demandar algum tempo. A conclusão final do processo de estabelecimento da UE corresponderia à supressão da soberania dos Estados-membros. Essa concepção norteou as primeiras discussões acerca da natureza da UE e envolve, de regra, uma visão "excludente". Ou seja, a qualificação de Estado não pode ser compartilhada simultaneamente pelos Estados-membros e pela UE. Reconhecer a natureza de Estado à UE significaria negá-la aos Estadosmembros e vice-versa.

Outra proposta, qualificada como "clássica heterodoxa", reconhece' ausência de perspectiva da UE realizar o modelo de Estado clássico, orientando-se antes ao desenvolvimento de uma forma peculiar própria, aproximada a uma confederação. Sob essa perspectiva, o destino da UE é o "modelo incompleto" em face dos tipos de Estados conhecidos. A configuração da UE como Estado nunca eliminaria um núcleo de soberania dos Estados-membros. Mais propriamente, deverá formular-se nova concepção de soberania, admitindo-se partilha de poderes entre órbitas políticas distintas. Nessa linha, por exemplo, CHRYSSOCHOOU qualifica a UE como uma confederação consociativa ${ }^{136}$. Essa concepção pode aproximar a UE antes a uma organização internacional do que a um Estado propriamente dito ${ }^{137}$.

Esta segunda concepção parece mais concorde com a realidde dos fatos. Ainda que seja impossível formular algum tipo de previsão para o futuro, pode supor-se que a evolução da UE tenderá a manter os contornos hoje existentes. Nesse caso, a estruturação comunitária futura acentuará a fragmentação do instituto da soberania. Algumas faculdades inerentes a um Estado soberano continuarão mantidas na órbita dos Estados-membros e outras serão assumidas pela "ordem global" ${ }^{138}$. Não será

136 New Challenges..., cit., p. 524 e ss.

137 Nesse sentido, DEIRDRE M. CURTIN e IGE F. DEKKER, The European Union as a "Layered'International Organization: Institutional Unity in Disguise, texto a integrar The Evolution of EU Law, organizado por CRAIG e DE BÚRCA.

138 Nesse sentido se posiciona NEIL MACCORMICK, The Masstricht-Urteil: Sovereignty Now, European Law Journal, vol. 1, $\mathrm{n}^{2} 3$, November 1995, pp. 259-266. O autor afima que "a mais apropriada análise das relações entre sistemas legais é pluralísticas antes do que monística e interativa antes do que hierárquica"(ob. cit., p. 264), do que resulta uma partilha da soberania entre os Estados-membros e a União. 
possível aplicar o conceito tradicional de soberania sob pena de negar-se natureza de Estado quer à ordem central quer aos Estados-membros. Há perspectiva de modalidade de associação peculiar entre Estados, caracterizada pelo equilíbrio entre as ordens parciais e a ordem global. Aí se acentua a originalidade da UE e a impossibilidade de seu enquadramento nos modelos tradicionais de Estado, em que a ordem global assume a soberania em todas as suas manifestações ${ }^{139}$. A virtude do projeto comunitário reside na fórmula de partilha dos poderes, de molde a permitir atuação permanente e superação das crises e conflitos entre Estados-membros.

No entanto, ainda que pertinente examinar a natureza jurídica da UE, essa indagação é, nos tempos atuais, inconveniente. A cogitação de uma Europa unificada, com supressão de peculiaridades locais, produz o reavivamento de diferenças ancestrais. O estabelecimento de um "Estado Europeu" supranacional desperta reações relevantes. O nacionalismo é incentivado pela perspectiva de supressão da autonomia local e submissão a estruturas políticas permeadas pela presença de antigos rivais. Se a questão da natureza jurídica da UE fosse levantada formalmente (através de um plebiscito, por exemplo), a reação popular seria provavelmente contrária ao surgimento de um Estado supranacional. Ou seja, propor a questão nesse contexto significa provocar tomada de posição negativa, que até então não existia. É uma daquelas situações em que formular a pergunta impõe resposta tão previsível quanto indesejada. Logo, melhor é não indagar nada, ao menos temporariamente, na expectativa de que as condições se modifiquem e permitam gama mais ampla de alternativas. Aplica-se, aqui, o que se poderia denominar de "princípio Schuman": deve construir-se a Europa antes de estabelecer qualquer proposta política, social ou jurídica de maior profundidade. Uma vez adquirida certa consistência econômica, enfrentar-se-á discussão mais profunda.

No contexto atual, a UE não é um Estado soberano, inclusive porque "não pode sê-lo" - ao menos, ainda não. Firmar a soberania da UE produziria efeitos tão negativos no âmbito dos Estados-membros que muitos poderiam retirar-se do projeto. A soberania (mais ou menos extensa) da UE será produzida e maturada através do processo construtivo que lhe é peculiar. Vai sendo conquistada através de pequenos passos, em que a redução da soberania nacional é compensada com outras vantagens $^{140}$. O futuro da UE depende de variáveis impossíveis de definição prévia, em longo prazo. O tema fundamental consiste no surgimento de um "povo europeu", da afirmação de vínculos entre as diferentes Nações. A dimensão de um Estado Europeu dependerá da intensidade e extensão da união do(s) povo(s) europeu(s).

139 Em inglês, difundiu-se a expressão "multileved State" ou "multileved constitucionalism" para indicar a proposta de um Estado organizado em diferentes niveis. Nesse sentido, INGOLF PERNICE, Multilevel Constitutionalism and the Treaty of Amsterdam: European Constitution-Making Revisited? em Common Market Law Review 36: 703-750, 1999.

140 Usualmente econômicas, deve reconhecer-se. A prosperidade de cada país é o motor fundamental que potencializa a unificação. 
As alterações geradas através do "projeto Europa" ainda não podem ser integralmente compreendidas. Mas existem certas manifestaçōes que devem ser ressaltadas, especialmente porque o "sonho da Europa unificada" obnubila algumas constatações nem sempre positivas. A ânsia de encontrar a saída para antagonismos políticos tão antigos e tradicionais afeta, por vezes, a avaliação crítica das realidades existentes e das perspectivas futuras.

Em primeiro lugar, é imperioso destacar as concepções ideológicas subjacentes ao modelo adotado para unificação européia. Trata-se da realização, em nível transnacional, das políticas neoliberalizantes ventiladas a propósito das economias nacionais. Seu núcleo ideológico corresponde à substituição da intervenção direta do Estado por manifestaçōes regulatórias. Consagra-se a concepção da suficiência do mercado para disciplinar as relações econômicas, mediante supervisão de entes independentes, de conformação não política. Até o presente, a Comissão tem atuado como uma espécie de "agência européia", assumindo a função de dispor sobre o mercado, com poderes oponíveis mesmo em face dos governos nacionais.

Em segundo lugar, deve ter-se em vista o alerta de CAPORASO, para quem a UE produziu profunda alteração nas relações de poder entre capital e trabalho, superando o equilíbrio de forças vigente ao longo das primeiras décadas do séc. XX. O projeto de UE ignora a perspectiva de uma "Europa Social", para acentuar a perspectiva de sua potencialização econômica. A organização da UE favoreceu o capital, em detrimento do trabalho. A liberdade de deslocamento dos capitais apresenta relevância muito maior do que a de locomoção de trabalhadores. Ou seja, assegurar ao trabalhador o direito de prestar seu serviço em qualquer Estado europeu é muito menos significativo do que facultar o livre e não controlado deslocamento do capital. Somando-se a liberdade de deslocação dos capitais com a liberdade de tráfego das mercadorias, eliminou-se o poder de barganha do trabalho. Os trabalhadores são constrangidos a submeter-se às condições impostas pelos capitalistas, sob pena de transferência dos postos de trabalho para outro local e substituição das mercadorias por produtos importados. Através do novo figurino europeu, o capitalismo escapou ao controle do Estado-Nação.

Em terceiro lugar, a existência da UE propiciou o sensível fortalecimento dos Executivos nacionais. É que, no âmbito comunitário, os Estados-membros são representados pelos respectivos Poderes Executivos, que não se subordinam aos limites da tripartição de poderes ${ }^{141}$. Lembre-se que o Conselho, integrado por representantes dos Executivos locais, é titular da maior parcela da competência normativa comunitária. Na medida em que o Direito Comunitário impōe-se na órbita interna de cada Estado-membro, resulta evidente que a autonomia dos Legislativos foi reduzida através da comunitarização. Até pode entender-se que os Executivos assumiram

141 Acerca do tema, confira-se THOMAS RISSE-KAPPEN, Exploring the Nature of the Beast: International Relations Theory and Comparative Policy Analysis Meet the European Union, Journal of Common Market Studies, vol. 34, n² 1, March 1996, p. 74. 
indiretamente competência legislativa interna: podem produzir, através da disciplina comunitária, o Direito interno dos próprios países. $\mathrm{O}$ resultado, no final das contas, parece ser uma espécie de "acordo de cavalheiros" entre os diversos Executivos europeus.

É interessante observar que o déficit democrático da UE mereceu muito maior atenção do que os efeitos desdemocratizantes produzidos no âmbito interno de cada Estado-membro. Quanto a esses, prevaleceram as concepções clássicas, caracterizando a atuação internacional como modalidade de atividade política, insuscetível de controle pelas demais instituições governamentais. Segundo a tradicão, a vontade "nacional", projetada no âmbito externo, não se submete a processos de cunho democrático. Os Estados-membros não estão dotados de instrumentos internos de controle da atuação de seus Executivos no âmbito comunitário ${ }^{142}$. Como se vê, o processo de comunitarização não pode ser reconduzido a uma concepção "zero ou um", em que a dimensão dos poderes corresponderia a uma espécie de operação aritmética ${ }^{143}$. Não é assim que se passa com o instituto do "poder". Redução formal de poder não significa necessariamente a diminuição efetiva — afirmativa paradoxal apenas no domínio da física tradicional. $O$ fortalecimento da UE é inquestionável, como também é indiscutível que tal se deu às custas da redução das competências dos Estados-membros. Mas isso não produziu o enfraquecimento deles. Muito pelo contrário, os Estados integrantes da UE nunca foram tão fortes e poderosos como no presente. $O$ fortalecimento da UE não produziu enfraquecimento dos Poderes Executivos, muito pelo contrário. Ademais, a redução das competências dos Estados-membros produziu acréscimo de poder dos operadores econômicos privados.

Em quarto lugar, não se olvide que o déficit democrático da UE se desdobra em dois planos. Há o plano europeu propriamente dito, em que se cogita da inadequada vinculação dos órgãos políticos comunitários ao "povo". Trata-se do problema de Estado tecnocrático que não aspira à condição de representante de uma Nação nem pretende inserir-se em contexto de soberania popular. Mas há também a dimensão externa, que envolve as propostas políticas deste corpo político em face dos demais países. A natureza não democrática da UE produz o temor de que possa constituir-se em instrumento para os Estados-membros desenvolverem em nome alheio políticas reprováveis e que nunca poderiam assumir em nome próprio e diretamente ${ }^{144}$.

Em quinto lugar, não seria excessivo afirmar que a UE se assemelha a um experimento de reprodução "controlada" da vida. Poder-se-ia falar em "engenharia genética política" para indicar essa modelação artificial das condições de geração e desenvolvimento desse organismo político. A UE é criação artificial, desenvolvida

142 A nāo ser por ocasião das eleições, quando os diferentes projetos teóricos são submetidos ao crivo do eleitor.

143 De tal modo que a redução do poder de um dos sujeitos corresponderia ao correspondente acréscimo de poder de outro.

144 Nesse sentido, MICHAEL SMITH, The European Union and a Changing Europe: Establishing the Boundaries of Order, Journal of Common Market Studies, vol. 34, $\mathrm{n}^{\circ} 1$, March 1996, p. 8. 
no segredo de laboratórios, um produto planejado da combinação de fatores manipulados tecnocraticamente. A UE mimetiza o nascimento e a evolução dos Estados ocidentais, resulta do planejamento tecnológico e da criatividade do espírito científico característico da Civilização Ocidental. Apesar de todas as incertezas, a UE revela a pretensão inquestionável de manipular a História. Não se negam nem as boas intenções nem as virtudes da UE, os quais são incontroversos. A questão é outra, atinente ao modelo adotado, que dispensa instrumentos tradicionais de controle político. Imagina-se que o poder de um Estado unificado europeu será utilizado inevitavelmente para a realização de valores positivos. Os riscos são evidentes.

Enfim, a UE poderá tanto transformar-se em Estado na acepção clássica como também consolidar-se como instituição política " pós-moderna", destinada a otimizar as relações entre os povos dos diferentes Estados-membros. A primeira alternativa propõe questões muito mais sérias do que a segunda. A principal indagação que levanta é essa: tendo em vista a natureza não democrática, propriamente autoritária, que entranha o processo de unificação européia, qual "Estado Europeu" que será gerado? Em última análise, outra é a questão: "Será desejável um Estado Europeu?", pergunta que pode (e deve) ser formulada tanto pelos europeus como pelos que não o são. Essas ponderações não envolvem tomada de posição contra a UE, mas sublinham a necessidade de avaliar sob diferentes perspectivas a convivência com esse complexo aparato de poder político-econômico. Por tudo isso, os demais povos têm escolha senão conhecer as instituições comunitárias e acompanhar seu crescimento, passo a passo, no mesmo ritmo em que se processa a unificação européia.

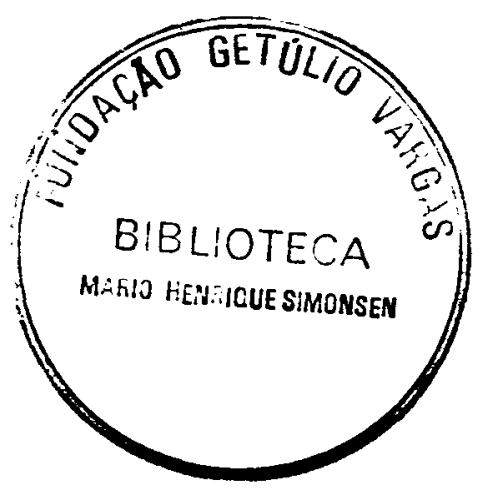




\section{Dicionário de Tecnologia Jurídica}

Pedro Nunes

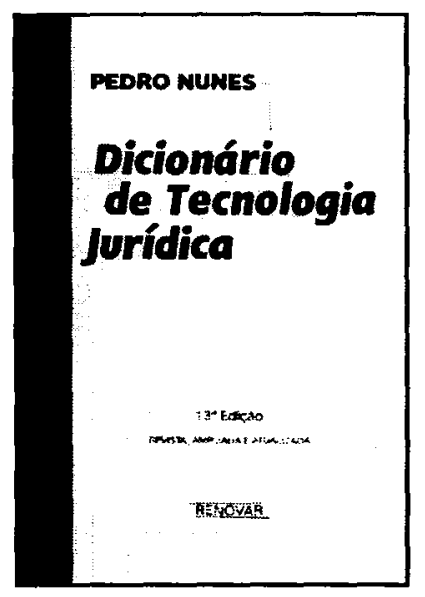

Esta obra representa um caminho de pesquisa seguro, para o estudante. O Atualizador nāo olvidou o material existente, antes procurou seguir o mesmo modo didático de se tratar cada verbete. Com efeito, mesmo ampliada, esta nova edição segue o mesmo padrão de tratamento para cada instituto jurídico. Este é um livro que, muito embora seja direcionado para um público, é também encaminhado a todos aqueles que, eventualmente, se deparam com termos jurídicos não conhecidos.

Ref. 0223

Form. 16x23

Encadernado 1999

1.198 págs. $13^{\mathrm{a}}$ edição

\section{Direito Agrário}

\section{Rafael Augusto de Mendonça Lima}

O autor enfatiza aqui o Estatuto da Terra e leis complementares e exalta a importância do Direito Agrário no âmbito legislativo, na doutrina e no ensino jurídico. O Direito Agrário tem princípios e institutos próprios, que servem como critérios para a elaboração das leis agrárias e para a sua interpretação. Essa é a matéria tratada neste livro, atualizada de acordo com a Constituição Federal de 1988, a legislação ordinária e a doutrina.

Ref. 0076

Form. 14x21
Brochura 1997
512 págs. $2^{\mathrm{a}} \mathrm{ed}$.
RNAEL AUGUSTO DE MARDONCA LIMA

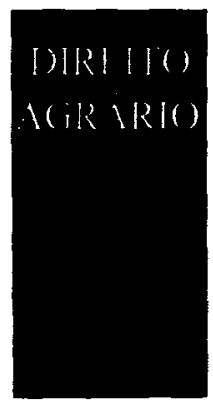

20 EOtcho 